\title{
E-CONTENT MODULE FOR CHEMISTRY MASSIVE OPEN ONLINE COURSE (MOOC): DEVELOPMENT AND STUDENTS' PERCEPTIONS
}

\author{
Siti Nurshuhada Mohd Hamid (D), Tien Tien Lee ${ }^{*} \mathbb{D}$, Hafsah Taha $\mathbb{D}$, \\ Nurulsaidah Abdul Rahim (D), Aisyah Mohamad Sharif $(\mathbb{D}$ \\ Department of Chemistry, Faculty of Science and Mathematics, Sultan Idris Education University \\ (Malaysia) \\ shubadabamid94@gmail.com, ${ }^{*}$ Corresponding author: lee.t@@fsmt.upsi.edu.my, hafsab@fsmt.upsi.edu.my, \\ saidab@fsmt.upsi.edu.my,aisyah@fsmt.upsi.edu.my
}

Received July 2020

Accepted September 2020

\section{Abstract}

This study aimed to develop an e-content module for Chemistry Massive Open Online Course (MOOC). It examined the validity, reliability and student's perceptions on content, usability, design and effectiveness of the module. This is a design and development study and the e-content module was developed based on ADDIE instructional design model. Collaborative learning, Connectivism theory and Interaction Equivalency Theorem are the pillars for the module development. The content validity of the module was estimated by three experts using content validity evaluation form. Questionnaires were distributed to the students in order to determine the reliability $(n=23)$ and students' perceptions on the module $(n=129)$. Findings revealed the e-content module has high content validity $(\mathrm{CVI}=1.00)$ and good reliability index $(\alpha=0.94)$. The mean scores for students' perception on module content $(\mathrm{M}=3.66, \mathrm{SD}=0.55)$, usability $(\mathrm{M}=3.43, \mathrm{SD}=0.56)$, design $(\mathrm{M}=3.41, \mathrm{SD}=0.59)$ and effectiveness $(\mathrm{M}=3.47, \mathrm{SD}=0.56)$ constructs were high. This e-content module in Chemistry MOOC is hoped to be a good and useful online resource for both lecturers and students in the teaching and learning of Chemistry in higher education institution.

Keywords - ADDIE model, Chemistry, Design and Development, Massive Open Online Course (MOOC), Perceptions.

\section{To cite this article:}

Hamid, S.N.M., Lee, T.T., Taha, H., Rahim, N.A., \& Sharif, A.M. (2021). E-Content Module for Chemistry Massive Open Online Course (MOOC): Development and Students' Perceptions. Journal of Technology and Science Education, 11(1), 67-92. https://doi.org/10.3926/jotse.1074

\section{Introduction}

Massive Open Online Course (MOOC) is a new paradigm in flexible education (Nganji, 2018) due to its flexibility to study anything regardless of time and geographical constraints (Alqahtani, 2019). It has the potential to attract massive number of learners to study courses unlimitedly via virtual online environment. MOOC aims to enhance the level of networking between learners and their communities, where learners receive the same knowledge and skills at the end of the program (Mackness, Mak \& Williams, 2010). This is in line with the criteria of lifelong learning which is an ongoing and voluntary 
learning to pursue knowledge (Hamidon, 2014). MOOCs provide unlimited chances for those who missed the higher education to enhance their education level (Mat-jizat, Samsudin \& Yahaya, 2014). Lifelong learning not only enhance social involvement and human development but also more resilient in competition and pursuit of employment.

MOOC refers to a virtual delivery model that allows large-scale interactive participation and open access to a set of freely accessible online resources providing the content or the study material (Baker, Bujak \& DeMillo, 2012; Littlejohn, 2013; Liyanagunawardena, Adams \& Williams, 2013). MOOC can be divided into two types, namely cMOOC and $\mathrm{xMOOC}$ with "c" representing connectivism and " $\mathrm{x}$ " representing exponential (Hollands \& Tirthali, 2014). The comparisons between cMOOCs and xMOOCs (Hollands \& Tirthali, 2014; Saadatdoost, Sim, Jafarkarii \& Hee, 2015) are presented in Table 1.

Community in MOOC communicates in either synchronous or asynchronous way (Baturay, 2015; Hervatta, 2016; Hollands \& Tirthali, 2014; Zhu \& Bonk, 2019). Synchronous communication occurs when all the community in the MOOC interact at the same time regardless of geographical location. In contrast, asynchronous communication occurs when the community in the MOOC interact freely at different time and location. Synchronous communication normally takes place using live video conferencing, text chats in real time while asynchronous communication occurs in the forums through discussions, comments, votes and peer evaluation. Synchronous communication technologies such as Google Hangouts, YouTube Live, as well as asynchronous communication technologies, such as discussion forums, blogs, Padlet, Slackbot, and various social media (e.g., Facebook) are widely used by MOOC instructors to support students' interaction and communication (Zhu \& Bonk, 2019).

\begin{tabular}{|c|c|c|}
\hline cMOOCs & Criteria & xMOOCs \\
\hline Connectivism & Learning theory & Behaviourism \\
\hline Knowledge construction & Teaching approach & Knowledge duplication \\
\hline Learner-centred & Learning approach & Teacher-centred \\
\hline Long & Duration & Cohort-based, fixed \\
\hline Flexible, fluid & Content & Structured, pre-determined \\
\hline Facilitator & Teacher's role & Material provider \\
\hline Information provider & Learner's role & Information consumer \\
\hline
\end{tabular}

Table 1. Comparisons between cMOOCs and xMOOCs (Hollands \& Tirthali, 2014; Saadatdoost et al., 2015)

\subsection{Background of Study}

In line with the ninth shift of Malaysia Education Blueprint 2015-2025 (Higher Education), Malaysia's Higher Education Institutions (HEIs) are recommended to globalize online learning (Figure 1). The shift was aimed to widen access to good quality content, improve the quality of teaching and learning, enhance online learning and highlight HEIs in international arena as well as nurturing lifelong learning specifically among Malaysians. The approaches proposed in the blueprint can be achieved through the offering of MOOCs in every HEI in Malaysia (Ministry of Education Malaysia, 2012).

Malaysia National e-Learning Policy (Dasar e-Pembelajaran Negara, DePAN) was enacted in 2011 to support National Higher Education Strategic Plan (Pelan Strategik Pengajian Tinggi Negara, PSPTN), where it focuses on the development of a quality e-learning framework. It aims to develop world-class human capital by using information and communication technologies. DePAN has five main pillars: (1) infrastructure, (2) organisational structure, (3) curriculum and e-content, (4) professional development and (5) acculturation (Ahmad, Hashim, Karimi \& Sin, 2010). Each pillar has specific focus area and activities to be implemented in three implementation phases: initial phase (2011-2012), implementation phase (2013-2014), and optimum phase (2015 upwards). 


\section{The 10 Shifts}

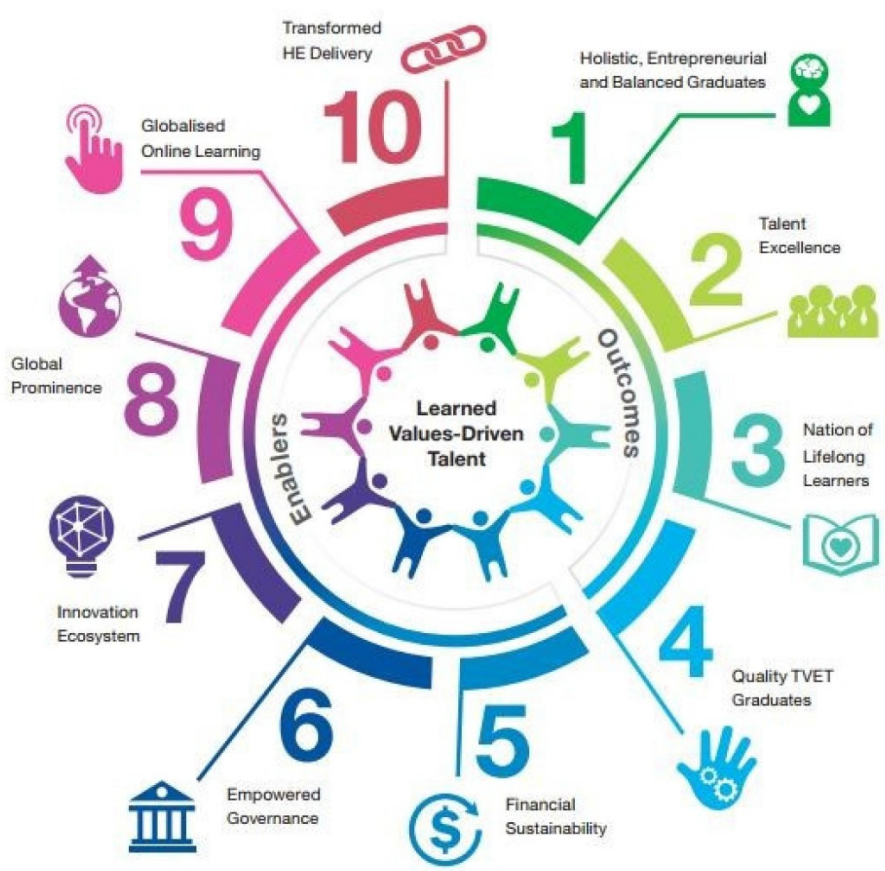

Figure 1. The 10 shifts in Malaysia Education Blueprint (Higher Education)

(Ministry of Education Malaysia, 2015)

Subsequently, the policy was revised to DePAN 2.0 (Ministry of Education Malaysia, 2015). The new policy is focusing on promoting innovation in education, branding of Malaysian education, bringing Malaysian expertise and skills to the global level, reducing delivery costs and fostering lifelong learning. DePAN 2.0 outlines the six main domains: (1) infrastructure and infostructure, (2) governance, (3) online pedagogies, (4) e-content, (5) professional development and (6) acculturation. DePAN 2.0 is implementing three phases starting with Phase 1 (2015), Phase 2 (2016-2020), and Phase 3 (2021-2025) (Department of Higher Education, n.d.). Some milestones to be achieved by online pedagogies in the three phases are shown in Table 2.

E-Learning in HEIs refers to a technology that enhances teaching and learning in an educational institution (Nichols \& Anderson, 2005). The use of e-learning software and hardware would create a more interactive, flexible and sophisticated teaching and learning environment. In Malaysia, most universities use their own e-learning system either the licensed open-source software or Learning Management System (LMS) which is equipped with a wide range of distinctive features that could facilitate online teaching and learning process.

\begin{tabular}{|c|l|c|c|c|}
\hline Domain & Focus area & Phase 1 (2015) & Phase 2 (2016-2020) & Phase 3 (2021-2025) \\
\hline \multirow{5}{*}{ Online pedagogies } & Blended learning & $\begin{array}{c}30 \% \text { of courses } \\
\text { offered by HEIs are } \\
\text { conducted in the } \\
\text { form of blended } \\
\text { learning }\end{array}$ & $\begin{array}{c}50 \% \text { of courses } \\
\text { offered by HEIs are } \\
\text { conducted in the } \\
\text { form of blended } \\
\text { learning }\end{array}$ & $\begin{array}{c}70 \% \text { of courses } \\
\text { offered by HEIs are } \\
\text { conducted in the } \\
\text { form of blended } \\
\text { learning }\end{array}$ \\
\cline { 2 - 5 } & Open course & $\begin{array}{c}\text { Each HEI offers a } \\
\text { minimum of 3 } \\
\text { MOOCs }\end{array}$ & $\begin{array}{c}\text { Each HEI offers a } \\
\text { minimum of } 15 \\
\text { MOOCs }\end{array}$ & $\begin{array}{c}\text { Each HEI offers a } \\
\text { minimum of } 30 \\
\text { MOOCs }\end{array}$ \\
\cline { 2 - 6 } & e-Assessment & $\begin{array}{c}5 \% \text { of e-Assessment } \\
\text { in blended learning }\end{array}$ & $\begin{array}{c}10 \% \text { of e-Assessment } \\
\text { in blended learning }\end{array}$ & $\begin{array}{c}15 \% \text { of e-Assessment } \\
\text { in blended learning }\end{array}$ \\
\hline
\end{tabular}

Table 2. The milestone for Domain 3: Online Pedagogies in DePAN 2.0 (Department of Higher Education, n.d.) 


\subsection{Problem Statement}

MOOC started to develop in Malaysia when Taylor's University offered their first MOOC course in 2013 as an alternative to traditional teaching and learning delivery methods (First MOOC, 2013; OpenLearning Global, 2014). Taylor's University offers their MOOC on openlearning.com. and it was announced to be the official online platform for Malaysia MOOCs. Since then, Malaysian Ministry of Education has commenced the implementation of MOOC in collaboration with four public universities in Malaysia as MOOC content developers. As a result, four MOOCs were first launched in openlearning.com. However, some HEIs faced some problems where their e-content is not getting the desired responses from lecturers and students compared to the traditional method (Ghani, 2012). In addition, Embi, Nordin, Husin and Hamat (2010) expressed the major challenges faced by the lecturers to integrate e-content in the teaching and learning sessions is balancing teaching with research and time constraints.

The milestone for the Phase 2 Domain 3: Online Pedagogies is each HEI offers a minimum of 15 MOOCs, however, statistics in 2018 showed most of the HEIs in Malaysia was not achieving that target (Hamid, 2020). Furthermore, statistics also showed that Chemistry MOOC in openlearning.com is still very low. Hence, Chemistry MOOC which consists of two types of modules i.e. e-content module and e-assessment module should be developed. The development of e-content module for this Chemistry MOOC provides guidance to lecturers to develop other MOOC. In addition, it also assists lecturers to facilitate the teaching and learning process in blended learning or flipped classroom. This study is implemented to design and develop e-content module for Chemistry MOOC in this regard.

\subsection{Research Objectives}

In general, this study aims to develop e-content module for Chemistry MOOC. Therefore, the objectives of this study are as follows:

1. Develop an e-content module for Chemistry MOOC using the ADDIE Model.

2. Estimate the content validity of the e-content module for Chemistry MOOC.

3. Estimate the reliability of the e-content module for Chemistry MOOC.

4. Identify students' perceptions in terms of content, usability, design and effectiveness of e-content module for Chemistry MOOC.

\subsection{Conceptual Framework}

The focus of this study is to develop the e-content module for Chemistry MOOC. ADDIE model was chosen as the instructional design model for the development of this Chemistry MOOC. During the analysis phase, four topics were selected as the content of this MOOC, namely Nuclear Chemistry, Quantum Theory and Periodic Table, Chemical Bonding and Stoichiometry of Formulas and Equations. Learning theories were studied and applied when the content of the MOOC is being designed. The theories involved are Collaborative Learning, Connectivism Theory and Interaction Equivalency Theorem. During the implementation phase, the Chemistry MOOC were introduced to three experts to check the content validity of the module. The reliability of the module was investigated during pilot study. Finally, perceptions of students on the module's content, usability, design and effectiveness were studied during the evaluation phase. Conceptual framework of the study is represented in Figure 2. 


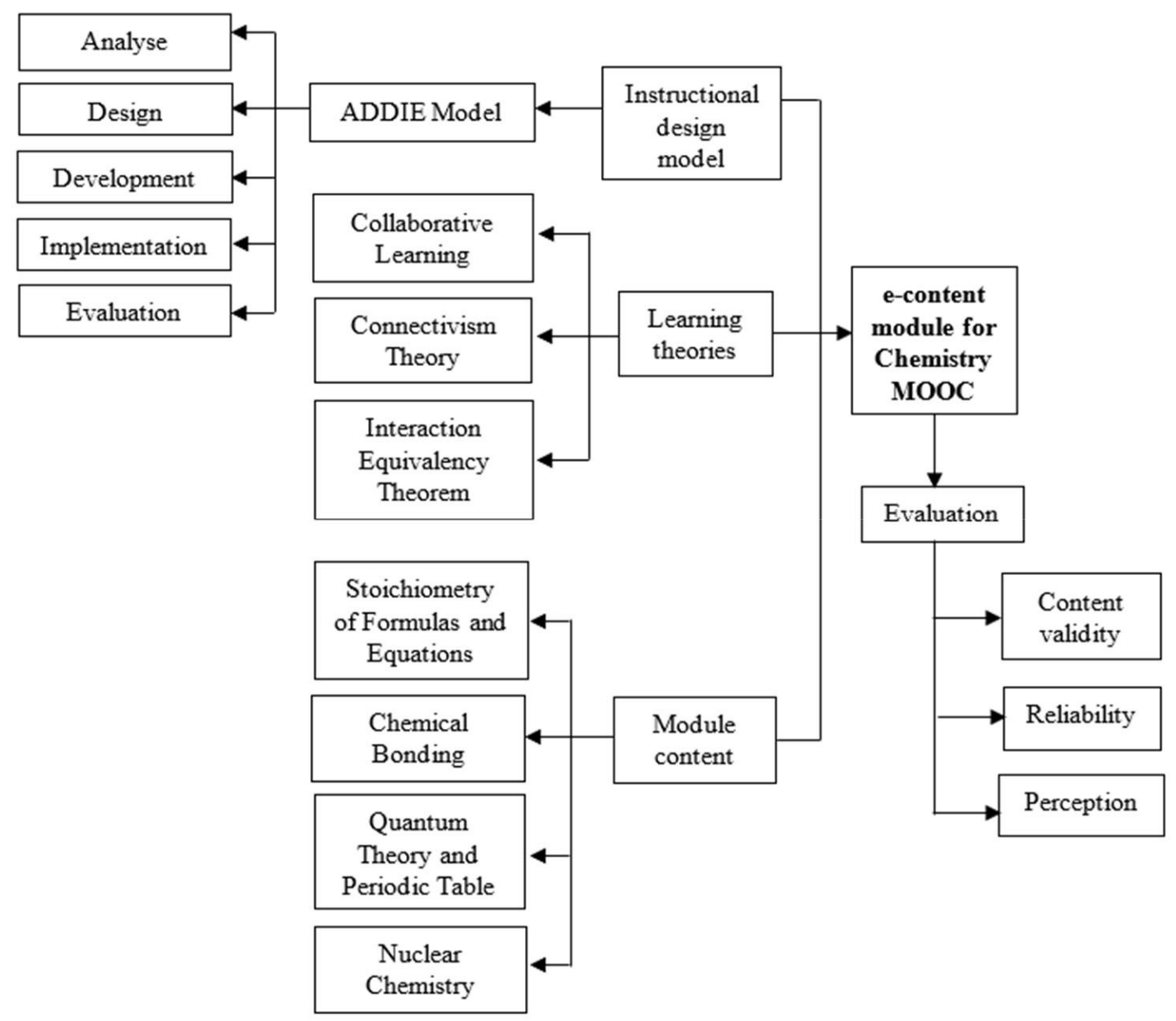

Figure 2. Conceptual framework of the study (Hamid, 2020)

\section{Methodology}

\subsection{Research Design}

This study is a design and development research to design and develop e-content module for Chemistry MOOC. This study also involves assessment studies aimed at estimating the validity, reliability and students' perceptions on the e-content module developed for Chemistry MOOC.

\subsection{Respondents}

This study involves the sampling of experts to evaluate the content validity of the module, sampling of students to access the reliability of the module and students' perceptions on the module. The purposive sampling technique was used to select the experts based on their knowledge in particular field or respondent wishing to be studied (Yahaya, Hashim, Ramli, Boon \& Hamdan, 2007). In this study, three experts were selected to evaluate the validity of the e-content module for Chemistry MOOC.

To estimate the reliability of the module, a total of 23 students in semester three were selected to answer the module reliability questionnaire. The semester three students have taken both Chemistry I (SKU3013) and Chemistry II (SKU3023) courses, hence they are eligible to evaluate the reliability of the e-content module designed for Chemistry course (SKU3063). The population of students under Bachelor of Education (Chemistry) program is approximately 190. According to Krejcie and Morgan (1970), the sample required is 127 . By using cluster random sampling technique, five groups of students from each semester have been selected to answer the students' perception questionnaire. The total respondents involved in the evaluation phase is 129 students. The demographic information of the respondents involved in this study is shown in Table 3 . 


\begin{tabular}{|c|c|c|c|}
\hline Purpose & Respondent & Number of respondents & Sampling technique \\
\hline Content validity & Expert & 3 & Purposive sampling \\
\hline Reliability & Student & 23 & Simple random sampling \\
\hline Perceptions & Student & 129 & Cluster random sampling \\
\hline
\end{tabular}

Table 3. Demographic information of respondents in the study (Hamid, 2020)

\subsection{Instrument}

Three instruments were involved in this study: the module content validity evaluation form, module reliability questionnaire and module perception questionnaire. The module content validity evaluation form consists of 49 items evaluating on the relevance of content presented to the learners (Polit \& Beck, 2006) based on the four topics in the Chemistry MOOC. The reliability of the module was evaluated based on the activities done by the learners (Noah \& Ahmad, 2005). A total of 72 items were asked and respondents need to answer the questionnaire based on 5-point Likert scale. The distribution of items in the module content validity evaluation form and module reliability questionnaire are shown in Table 4. The content validity of the module was analyzed by using Content Validity Index (CVI) (Polit \& Beck, 2006). The reliability of the module was analyzed by using Cronbach's alpha index while the perceptions of module were analyzed by using mean and standard deviation. The perceptions of the e-content module were evaluated based on content, usability, design and effectiveness of e-content module for Chemistry MOOC. The items in the perception questionnaire were adapted from the previous study (Lee \& Osman, 2012; Lee, 2013). The content validity of the perception questionnaire was checked by experts $(\mathrm{CVI}=1.00)$ and the reliability index of the questionnaire is 0.94 . The distribution of items in the perception questionnaire is shown in Table 5.

\begin{tabular}{|l|c|c|c|c|}
\hline \multirow{2}{*}{\multicolumn{1}{|c|}{ Topic }} & \multicolumn{2}{c|}{$\begin{array}{c}\text { Module content validity } \\
\text { evaluation form }\end{array}$} & \multicolumn{2}{c|}{$\begin{array}{c}\text { Module reliability } \\
\text { questionnaire }\end{array}$} \\
\cline { 2 - 5 } & $\begin{array}{c}\text { Distribution } \\
\text { of item }\end{array}$ & Total item & $\begin{array}{c}\text { Distribution } \\
\text { of item }\end{array}$ & Total item \\
\hline Stoichiometry of Formulas and Equations & $1-12$ & 12 & $1-18$ & 18 \\
\hline Quantum Theory and Periodic Table & $13-24$ & 12 & $19-36$ & 18 \\
\hline Chemical Bonding & $25-37$ & 13 & $37-55$ & 19 \\
\hline Nuclear Chemistry & $38-49$ & 12 & $56-72$ & 17 \\
\hline
\end{tabular}

Table 4. Distribution of items in the module content validity evaluation form and module reliability questionnaire

\begin{tabular}{|l|c|c|c|c|}
\hline \multicolumn{1}{|c|}{ Constructs } & Distribution of items & Total item & Validity & Reliability \\
\hline Content & $1-9$ & 9 & & \multirow{2}{*}{1.00} \\
\hline Usability & $10-15$ & 6 & 0.94 \\
\hline Design & $16-23$ & 8 & \\
\hline Effectiveness & $24-32$ & 9 & & \\
\hline
\end{tabular}

Table 5. Distribution of items in perception questionnaire (Hamid, 2020)

\subsection{Module Development Procedure}

The first objective of this study is to develop the e-content module for Chemistry MOOC. It was developed based on the ADDIE model, following the five phases in the ADDIE model: analysis, design, development, implementation and evaluation phase.

\subsubsection{Analysis Phase}

The analysis phase is an initial phase in a design and development study involving information in the context and environment to be studied (Siraj, Alias, DeWitt \& Hussin, 2013). Need analysis needs to be carried out before the module is developed for identifying probable causes of problems (Branch, 2009) 
and take action to resolve existing problems (Reinbold, 2013). In this study, the analysis has been divided into two parts: assessment needs analysis and module requirements analysis (Low, 2014).

The assessment needs analysis was carried out to choose the appropriate titles to be developed in MOOC and suitable for online learning students. Chemistry course (SKU3063) consists of seven topics, namely Stoichiometry of Formulas and Equations, Gaseous and the Kinetics-Molecular Theory, Quantum Theory and Periodic Table, Chemical Bonding, Electrochemistry, Chemical Equilibrium and Nuclear Chemistry. An online questionnaire was distributed to the lecturers at the Department of Chemistry to choose the appropriate topics to be developed in the e-content module in Chemistry MOOC. The selection of topics is also based on students' problems and weaknesses in learning basic chemistry concepts.

The findings of need analysis found four of the seven topics in Chemistry course (SKU3063) received the highest percentage. The topics are Nuclear Chemistry (65\%), Quantum Theory and Periodic Table (55\%), Chemical Bonding (55\%), and Stoichiometry of Formulas and Equations (45\%) as shown in Figure 3. The results are paralleled with the result found in another need analysis carried out by Lee, Sharif and Rahim (2018) which reported university students were weak in Matters and Measurements, Periodic Relationship among the Elements, Stoichiometry and Chemical Reactions. Therefore, these four topics were chosen to be included in the e-content module for Chemistry MOOC.

Module requirement analysis was carried out to analyze the specification of the module based on the results of assessment needs analysis. Module requirement analysis identified the objectives of the module, target users, content of the module, learning theories and pedagogy involved in the delivery of content in the module. The objectives of developing this e-content module for Chemistry MOOC is to create online learning materials for basic chemistry concepts in Chemistry course (SKU3063) to enable students to access the material regardless of time and geographical constraints. Lecturers can use this e-content module as one of the resources for their blended learning or flipped classroom platform. On the other hand, students can use this module as self-paced material to learn basic chemistry concepts. Hence, the target users of this econtent module are lecturers and students who wish to teach or learn basic chemistry concepts at university level especially those who enroll for the SKU3063 Chemistry course.

Based on the results of need analysis, four topics had been included in the course: Nuclear Chemistry, Quantum Theory and Periodic Table, Chemical Bonding, and Stoichiometry of Formulas and Equations. The structure of the topics is shown in Figure 4. Since the module was part of the Chemistry MOOC and is implemented online, the learning theories and pedagogy employed should be aligned with the characteristics of e-learning.

Students could access the e-content module individually either synchronously or asynchronously in Chemistry MOOC. Lecturers post questions or problems in the Chemistry MOOC (Figure 5), and students share knowledge, discuss and work together to solve the problems (Figure 6). Hence, e-learning environment encourage students to learn and share through collaboration (Baser, Ozden, \& Karaarslan, 2017; Duke, Harper \& Johnston, 2013). This collaborative learning enables students to help each other and achieve the intellectual, social and problem solving learning goals in the classroom (Baharin \& Yusop, 2011).

Two learning theories: Connectivism Theory and Interaction Equivalency Theorem which are closely related to online learning environment were applied in the design and development of e-content module. Connectivism is the integration of principles explored by chaos, network and complexity and self-organization theories (Siemens, 2005). It offers specific technological opportunities for users to be actively engaged in the presentation of a body of knowledge (Duke et al., 2013). This engaged learning requires collaborations among the community in the e-learning environment (Conrad \& Donaldson, 2004). Hence, connectivism is also defined as actionable knowledge (Duke et al., 2013) because the learners need to find the related knowledge in the e-learning platform. 


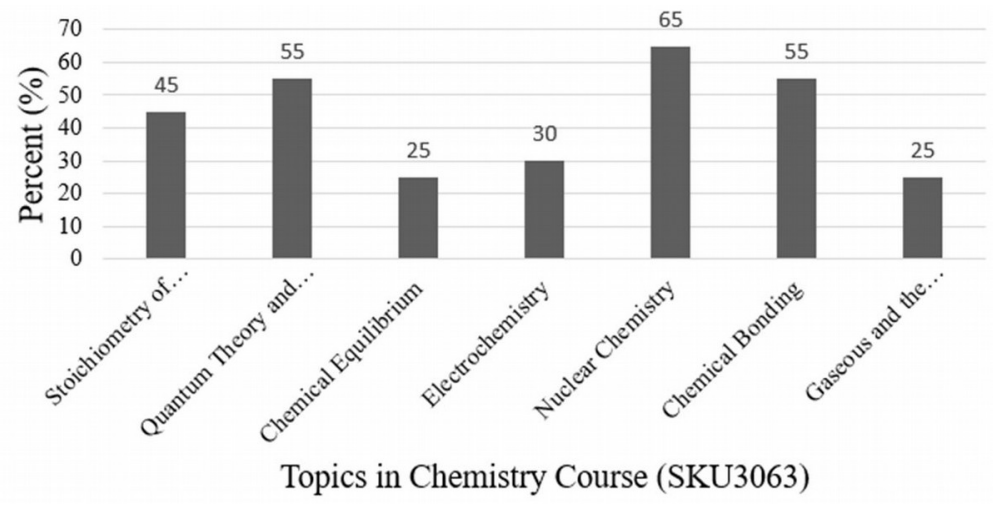

Figure 3. Percentage of topic selection in Chemistry Course (SKU3063) among the lecturers (Hamid, 2020)

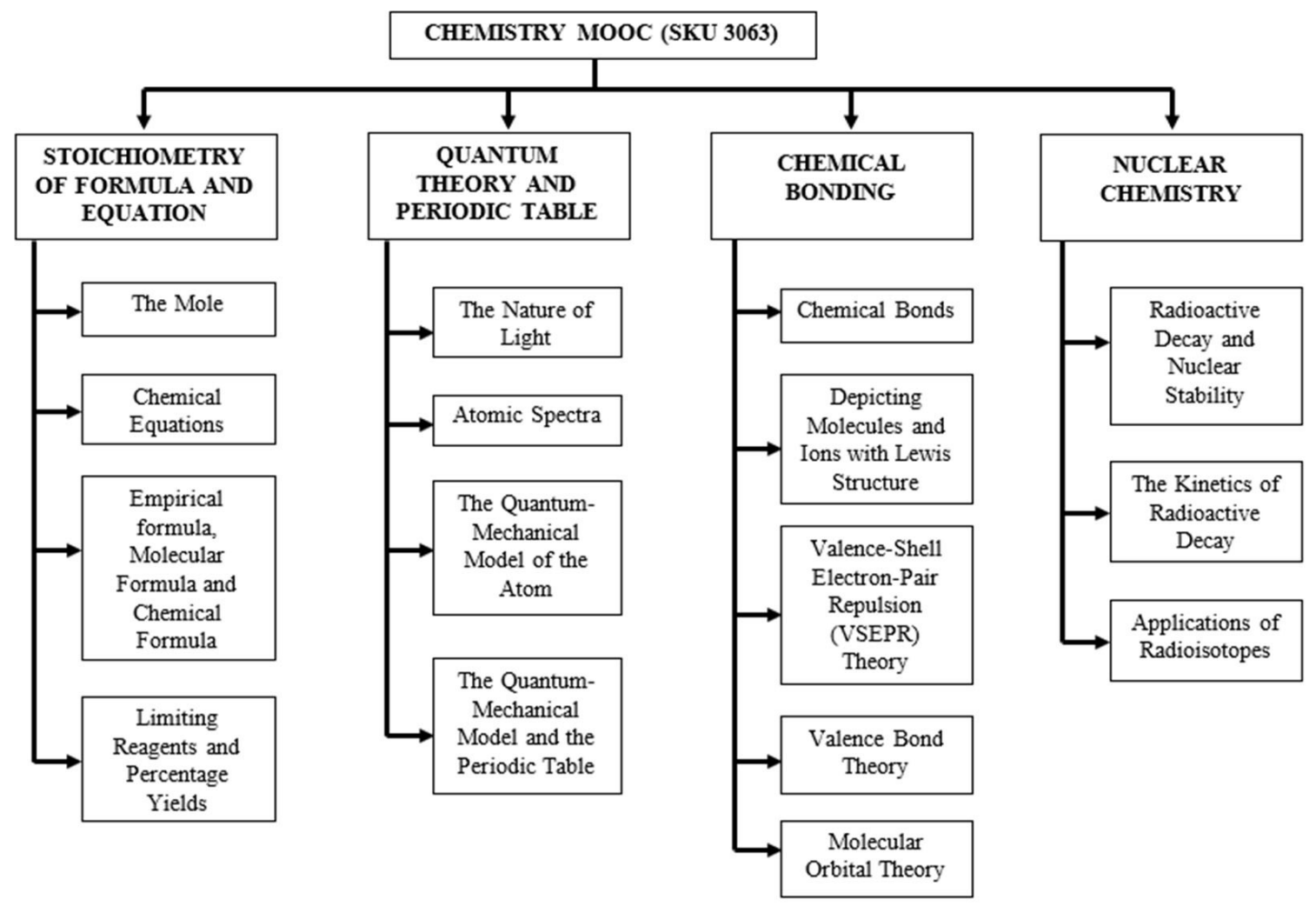

Figure 4. Structure of the topics for the e-content module (Hamid, 2020)

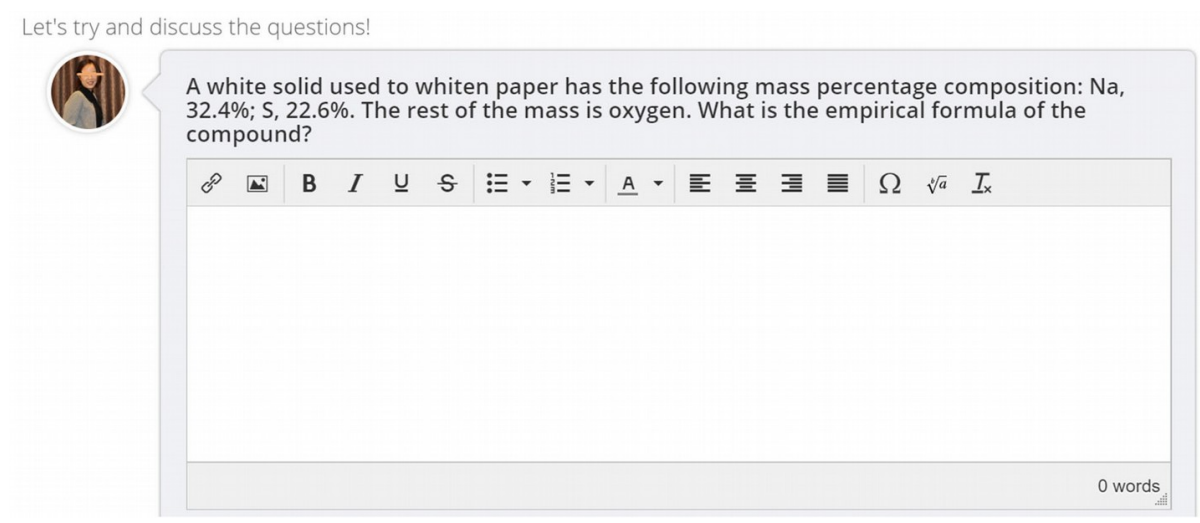

Figure 5. An example of question posted in the module 

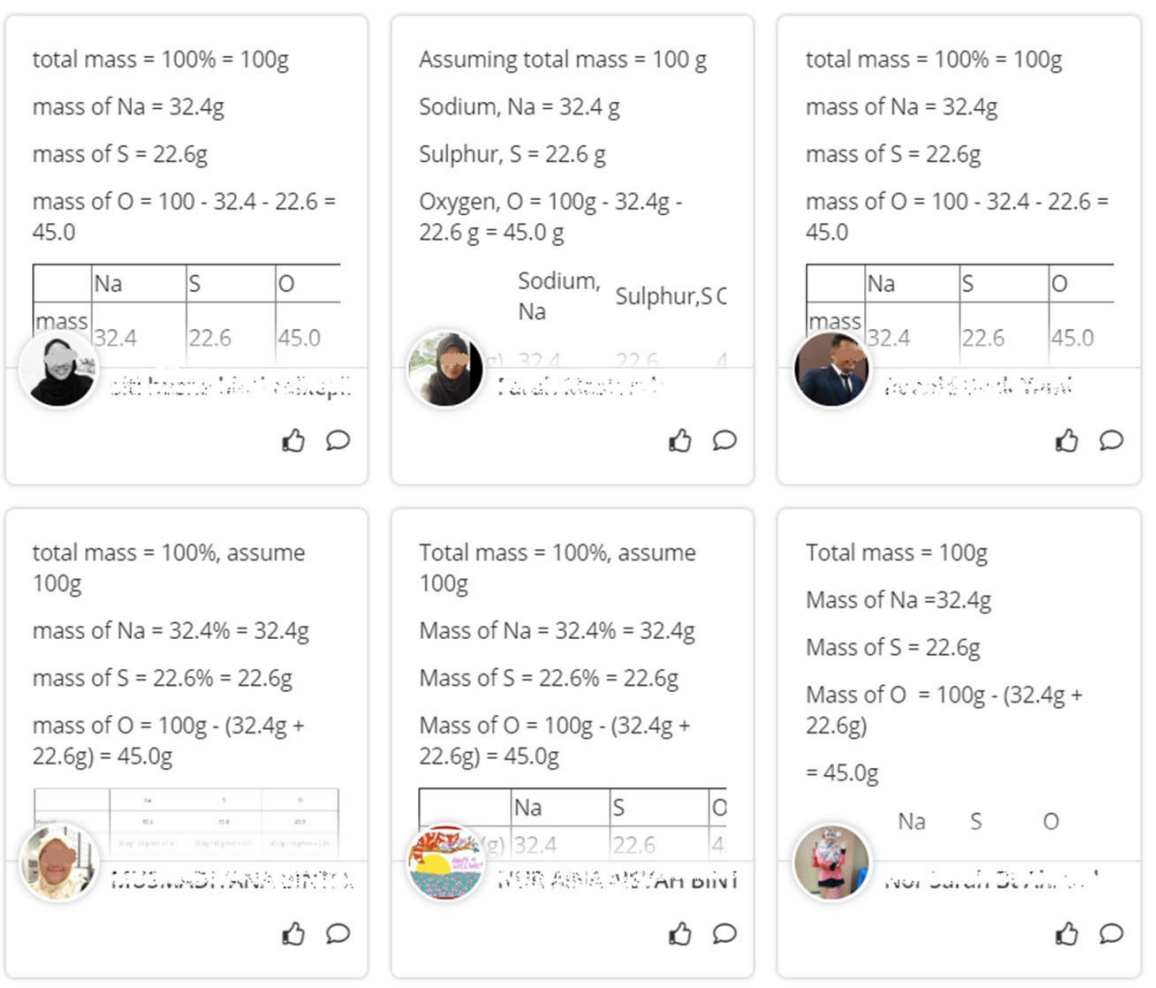

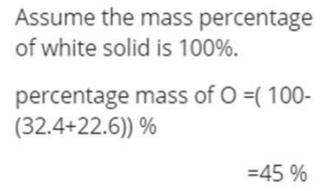

Assume the mass percentage of white solid is $100 \%$.

percentage mass of $\mathrm{O}=(100$ $(32.4+22.6)) \%$$$
=45 \%
$$

Assume the mass of white solid is $100 \mathrm{~g}$, so

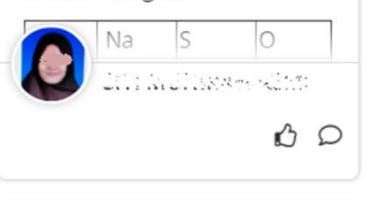

Total mass $=100 \%$, assume $100 \mathrm{~g}$

Mass of $\mathrm{Na}=32.4 \%=32.4 \mathrm{~g}$

Mass of $\mathrm{S}=22.6 \%=22.6 \mathrm{~g}$

Mass of $\mathrm{O}=100 \mathrm{~g}-(32.4 \mathrm{~g}+$ $22.6 \mathrm{~g})=45.0 \mathrm{~g}$

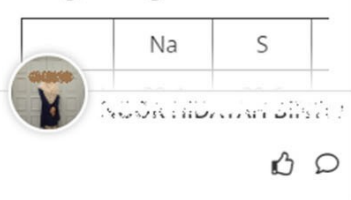

Figure 6. Examples of answers shared by students

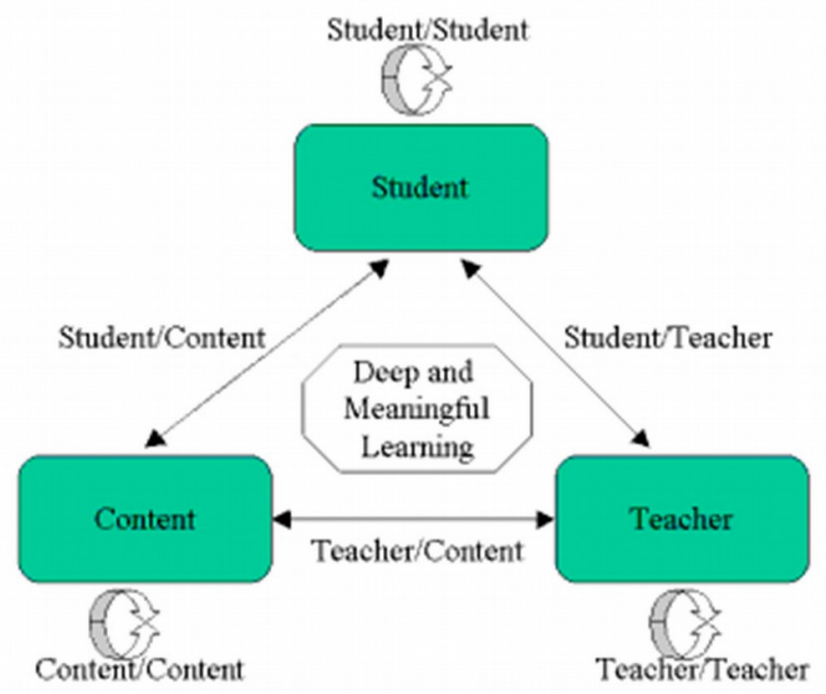

Figure 7. Mode of interactions in distance education (Anderson \& Garrison, 1998)

Community in the Chemistry MOOC consists of students, lecturers and content of the e-content module. Each party in the community is involved and connected to each other in the teaching and learning process. The mode of interactions in the Chemistry MOOC are student-student, student-teacher, student-content, teacher-teacher, teacher-content and content-content (Figure 7). These interactions were described by Anderson and Garrison (1998) as Interaction Equivalency Theorem.

Two theses were proposed from the Interaction Equivalency Theorem as follows (Anderson, 2003: page 4).

Deep and meaningful formal learning is supported as long as one of the three forms of interaction (student-teacher; student-student; student-content) is at a high level. The other two may be offered at minimal levels, or even eliminated, without degrading the educational experience. 
High levels of more than one of these three modes will likely provide a more satisfying educational experience, though these experiences may not be as cost or time effective as less interactive learning sequences.

Both theses illustrate the Interaction Equivalency Theorem in terms of quality and quantity. The first thesis focuses on the quality of interaction. If one of the interactions is conducted in quality, deep and meaningful learning is possible. In contrast, the second thesis focuses on the quantity of interactions. The thesis suggests that all three parties (teachers, students and content) need to interact regularly to ensure that learning is meaningful.

\subsubsection{Design Phase}

The design phase is started after the analysis phase. Before designing, specifications of the module requirements that have been identified in the analysis phase needed to be checked again. This is important to ensure the design of e-content module for Chemistry MOOC is based on specification of module that has been planned in the analysis phase. In this phase, specifications of the module's requirements may still be modified or corrected if there is any disadvantage to ensure that it is complete, and no modification should be made during the development phase. This phase is mainly focuses on the design of module's content.

The e-content module for Chemistry MOOC is divided into three main components, (1) learning outcomes and advance organizer, (2) learning material and (3) exercises. Storyboard (Figure 8) was used as a guidance in designing the content of the module based on the proforma (document stating the synopsis, learning outcomes and structure of the course) of the Chemistry course (SKU3063). Learning outcomes list all objectives needed to be achieved by students at the end of each topic while advance organizer provides the overview of each topic (Figure 9). Learning outcomes and advance organizer serve as outline for each topic in the e-content module. This outline helps learners to develop better strategies to achieve their learning goals and finally succeed in MOOC learning (Handoko, Gronseth, McNeil, Bonk \& Robin, 2019).

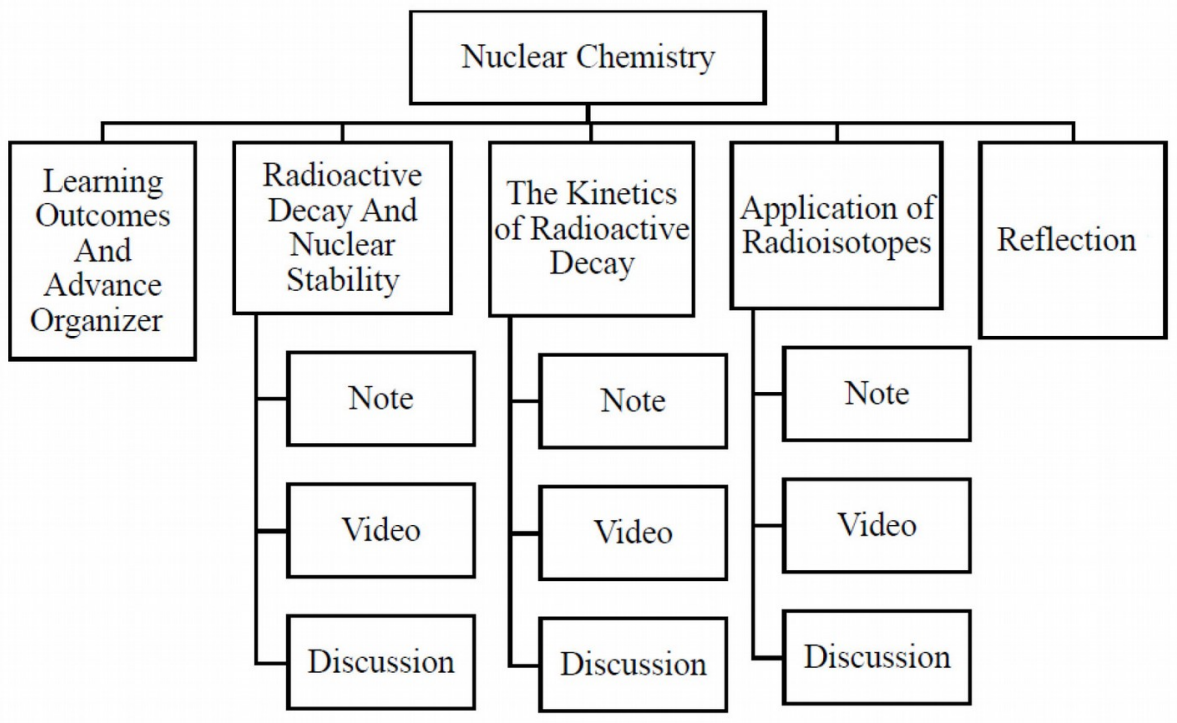

Figure 8. Storyboard used in designing the content of module (Hamid, 2020) 


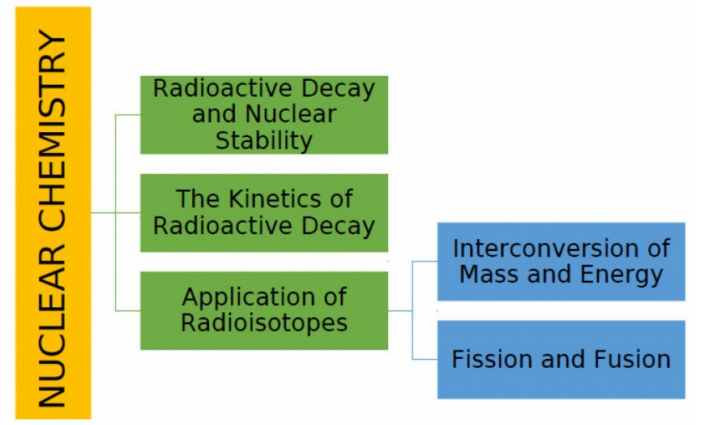

Figure 9. An example of an advance organizer in a topic (Hamid, 2020)

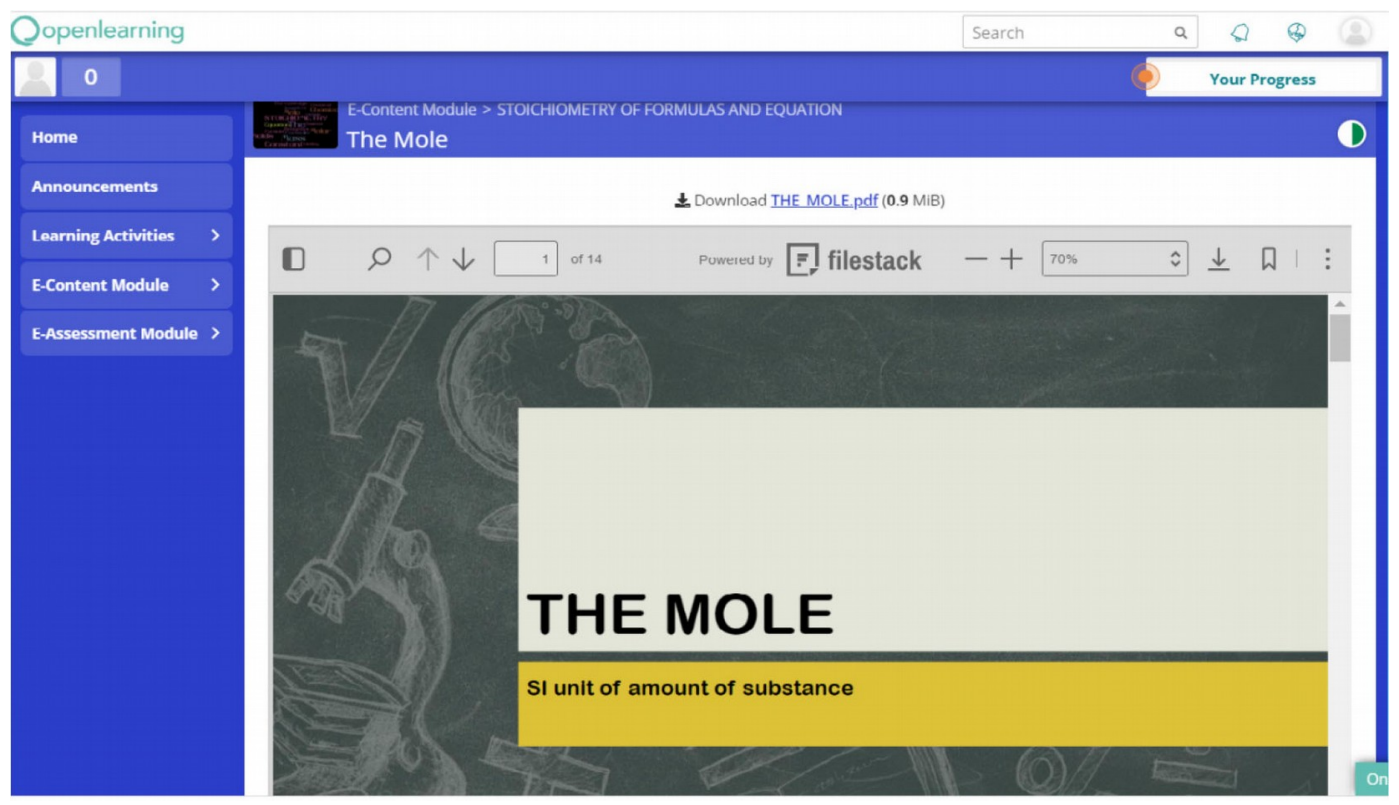

Figure 10. An example of notes in PowerPoint slides

Learning material in the e-content module mainly consists of notes in the form of PowerPoint slides and videos. The notes were designed by using Microsoft PowerPoint (Figure 10), based on content in the reference books written by Blackman, Bottle, Schmid, Mocerino, Wille, Brady et al (2016) and Silberberg (2013) and notes from the other two basic chemistry courses (SKU3013 and SKU3023). Videos (Figure 11) related to the topics were downloaded from YouTube with duration of not more than 12 minutes. It is reported the best duration of online videos is six minutes in order to attract and sustain students' attention and ensure their engagement to the videos (Guo, Kim \& Rubin, 2014; Lagerstrom, Johanes \& Ponsukcharoen, 2015). A list of URL links for all videos downloaded from YouTube is enclosed at the end of each topic in the e-content module as an acknowledgement to the owners of the videos. Hence, it is considered as fair use of copyright in online education (Ministry of Education Malaysia, 2014).

Exercises are provided via the discussion page at the end of each topic (Figure 5) and they are open for discussion. Students could share their answers in the space provided (Figure 6). Hence, students in the e-content module can work together to solve the problems collaboratively. Not too many questions are posted in the e-content module because there is an e-assessment module (Figure 12) in the Chemistry MOOC which is focusing on giving exercises to the students. Exercises in the discussion page serve as formative assessment to ensure students master the topic before moving to another topic. This discussion page enables students to use peer assessment to help students' self-monitoring (Zhu \& Bonk, 2019). 


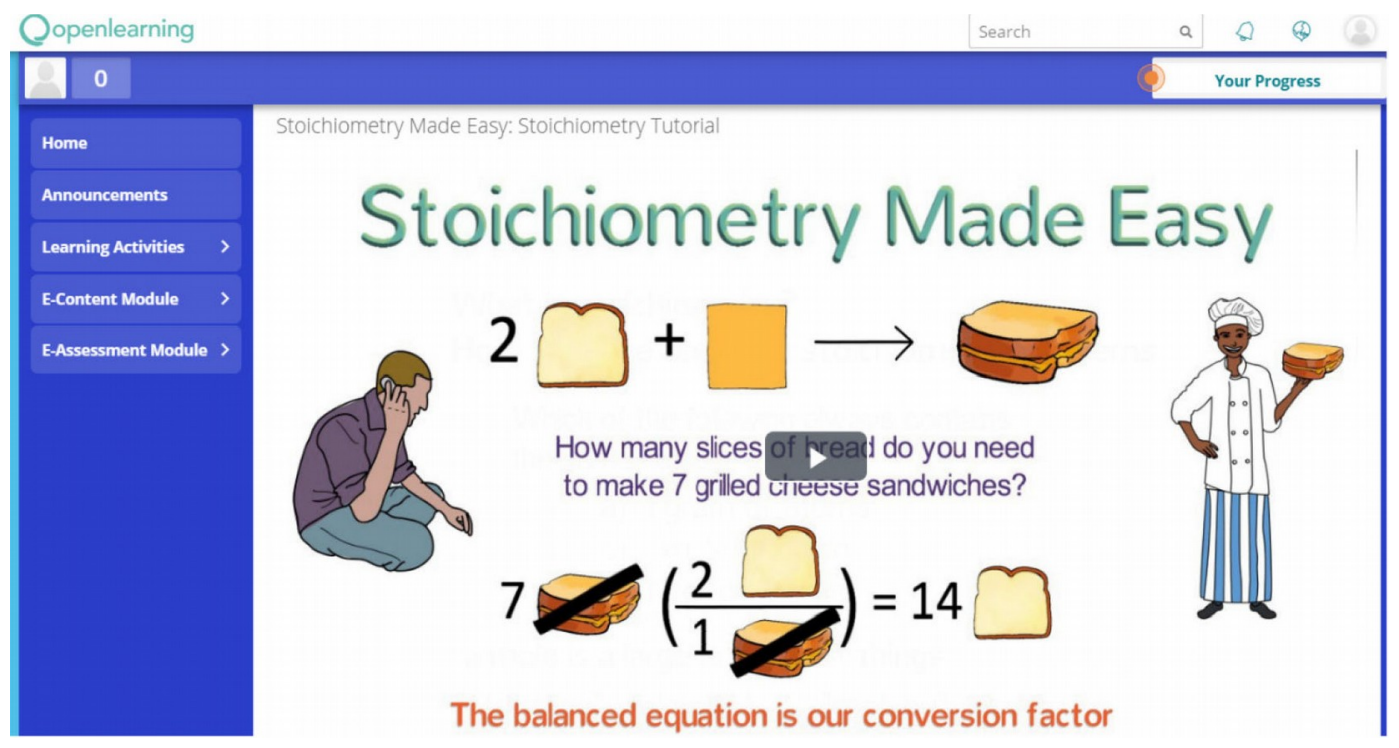

Figure 11. An example of video in the e-content module

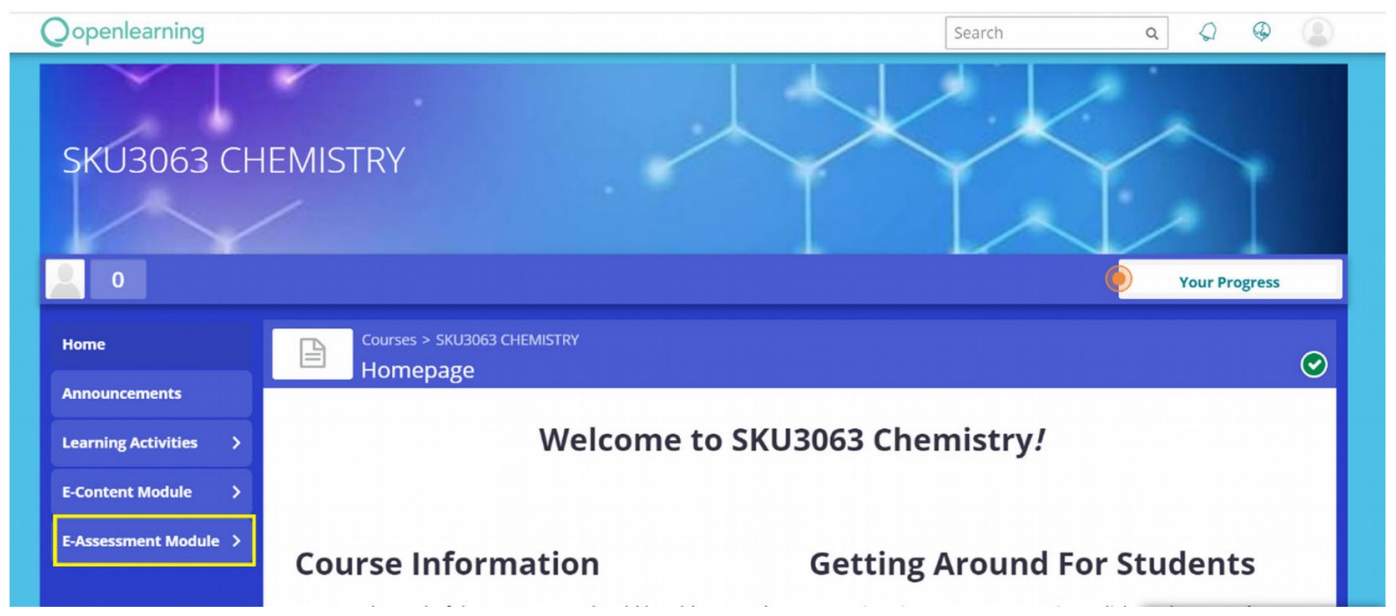

Figure 12. An e-Assessment module in Chemistry MOOC

\subsubsection{Development Phase}

The development phase in this study is a phase that determines the tools and process of creating the e-content module in Chemistry MOOC. This phase was initiated after the design phase had fulfilled the specifications set in the analysis phase. This phase involves the process of generating materials needed to achieve the targeted objectives. The e-content module is part of material in Chemistry MOOC. The platform chosen to create the Chemistry MOOC is OpenLearning. Firstly, we need to register an account in OpenLearning platform by logging into OpenLearning homepage. Then click at 'Sign up' button to create an account (Appendix 1.1).

Second, we have to register our MOOC at OpenLearning by clicking at 'Create a Course' button (Appendix 1.2). After successfully register the course we can start developing the e-content module navigation button on the main menu (Appendix 1.3). From the 'Course Setup' menu, choose 'Content', then type our module's name at the 'Create a new module set' and finally click at the 'Create' button. There are two modules in this Chemistry MOOC, the e-Content Module and the e-Assessment Module. However, this paper will only focus on the development of the e-Content Module. Next, we need to develop the content of the e-content module. The first topic of e-content module is Stoichiometry of Formula and Equation. We insert the title of the topic in the 'Add a New Module' box to create the title of the topic (Appendix 1.4). 
During the Design phase, we have determined that there are three main components in each topic, namely (1) learning objectives and advance organizer, (2) learning material and (3) exercise. Hence, we need to develop these three components by adding page in the module. First step is developing the 'Learning Outcomes and Advance Organizer' page (Appendix 1.5). We need to click at the 'Edit page' button to develop the content in this page. In this e-content module, all the learning outcomes to be achieved by the students for each topic are presented in the form of videos. There are some widgets in the edit page interface. We need to click and drag the 'Video' widget to the right section of the screen to upload the video (Appendix 1.6). Videos can be uploaded by using URL or files saved in the computer.

We also can insert picture in the page. The Advance Organizer in each topic is presented in the form of picture. So, we can use the 'File' widget to upload the picture. Click and drag the 'File' widget to the right section of the screen and insert picture from the file saved in our computer (Appendix 1.7). After editing the 'Learning Outcomes and Advance Organizer' page, we add another page to create the content for the learning material. The first subtopic of 'Stoichiometry of Formulas and Equation' is 'The Mole'. We click at the 'Add a page' button and type the title of the subtopic in the box (Appendix 1.8).

Learning materials normally starts with notes in the form of PowerPoint slides. Hence, the 'File' widget is used to develop the content. Click and drag the 'File' widget to the right section of the screen and upload the PowerPoint slides saved in the computer (Appendix 1.9). The third component is the exercise. We need to use the "Post file" widget to develop the Discussion page. Click and drag the 'Post file' widget to the right section of the screen. Next type the question in the setup part in 'Post file' widget (Appendix 1.10). Lastly, we need to test all links and navigation buttons in the e-content module to ensure all the navigations function well. Then we need to change the status of Chemistry MOOC from offline to online at 'General' interface from 'Course Setup' (Appendix 1.11). OpenLearning platform provides the URL so that we can share the Chemistry MOOC to others. The course promotional page (Figure 13) will be displayed when the URL is typed in the online system.

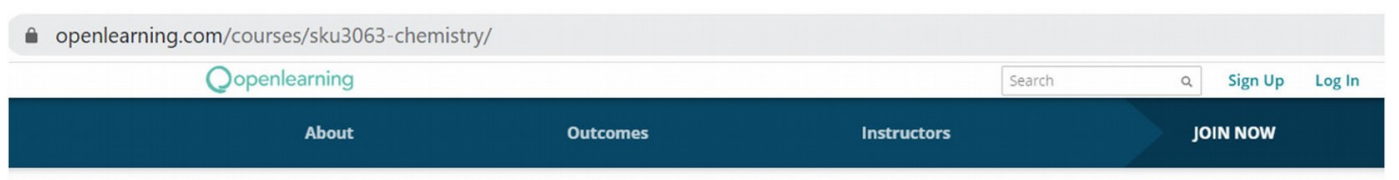

\section{SKU3063 CHEMISTRY}
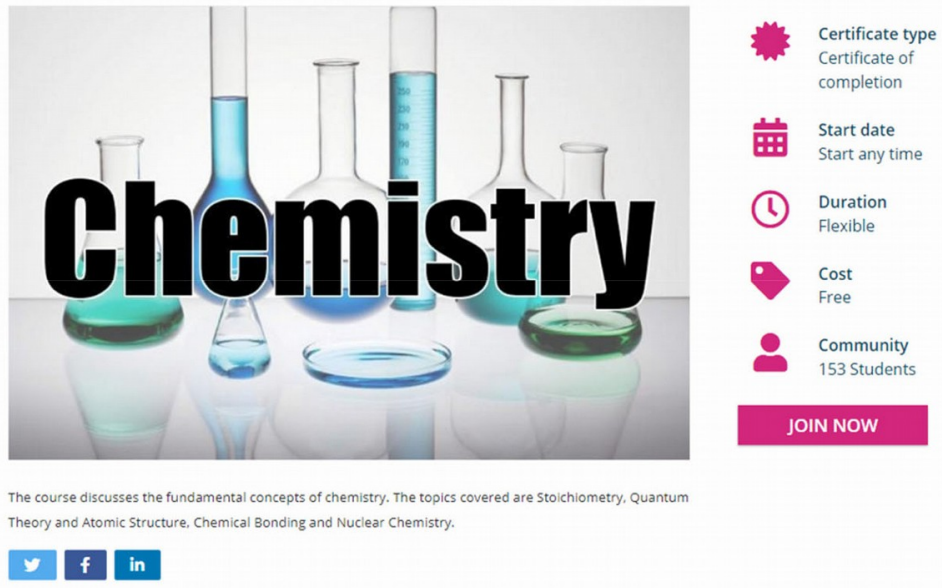

Figure 13. Promotional page of Chemistry MOOC 


\subsubsection{Implementation Phase}

During the implementation phase, the e-content module for Chemistry MOOC which has been developed in OpenLearning platform is now fully accessible to all users. In this phase, the validity and reliability of the module is estimated during the pilot study. According to Russell (1974), a module with good content validity should fulfil the following characteristics:

a) meet the target population,

b) satisfying situation for the implementation of the module,

c) sufficient time for the learners to access the module,

d) able to increase learner's achievement after using the module,

e) able to improve learner's attitude after using the module.

Ahmad (2002) developed a content validity evaluation form which followed Russell's characteristics of good module. However, there were only five items in the evaluation form. Hence, content validity evaluation form in this study was developed by modifying the way of obtaining the content validity index of instrument (Polit \& Beck, 2006). Three experts were assigned to evaluate the relevance of the material developed in the e-content module. They were briefed on how to use the Chemistry MOOC and were introduced with the e-content module in Chemistry MOOC. The content validity evaluation form was distributed to the experts and they were given two months to evaluate the content validity of the module.

Russell (1974) stated the reliability of a module can be determined when the respondent is able to dominate the objectives and able to follow the steps for each activity in the module successfully. Hence, module reliability questionnaire had been developed following the sequence of activities provided in each topic in the e-content module in Chemistry MOOC. In this study, the respondents of the pilot study were students from Bachelor of Education (Chemistry) program who had taken Chemistry I (SKU3013) and Chemistry II (SKU3023) courses. The students were gathered and briefed on OpenLearning as well as how to use e-content module in Chemistry MOOC. They were given a month-long time to access the Chemistry MOOC and go through the learning process using the e-content module. After that, the respondents were asked to answer the reliability questionnaire. Upon completion of the implementation phase, the next phase is the evaluation phase.

\subsubsection{Evaluation Phase}

The evaluation phase of the ADDIE model is a continuous process in each phase in the development of e-content module for Chemistry MOOC. The aim of the evaluation phase is to assess the quality of the instructional products and processes, both before and after implementation (Branch, 2009). During this evaluation phase, the weaknesses and problems faced during the development of the e-content module are identified so that amendments could be made. The evaluation can be carried out in both formative and summative evaluation.

Formative evaluation is carried out to determine the potential effectiveness of learning resources under development and to identify any learning resources or parts thereof that need to be revised (Branch, 2009). It has been carried out concurrently with analysis, design, development and implementation phases in three typical ways, one-to-one trial, small group trial and field trial (Branch, 2009). Supervisor, all the research team members and experts were involved in checking and monitoring the process of designing and developing the e-content module. Supervisor checked the content in the mode of one-to-one trial, research team members and experts carried out the formative evaluation in small group trial and finally students in the pilot study access the e-content module in field trial. Comments and suggestions from the experts were taken into consideration and corrections were done after discussing with supervisor and research team members. Some of the issues raised up by the experts were related to the content and the use of instructional media. They also gave some ideas regarding the design of the learning material and they suggested us to create the reflection page (Figure 14) for the learners to reflect on what they have learnt in each topic and share their thoughts (Figure 15). This is a useful strategy to facilitate students' metacognitive process in MOOCs by encouraging them to have self-reflection and self-monitoring (Zhu \& Bonk, 2019). 


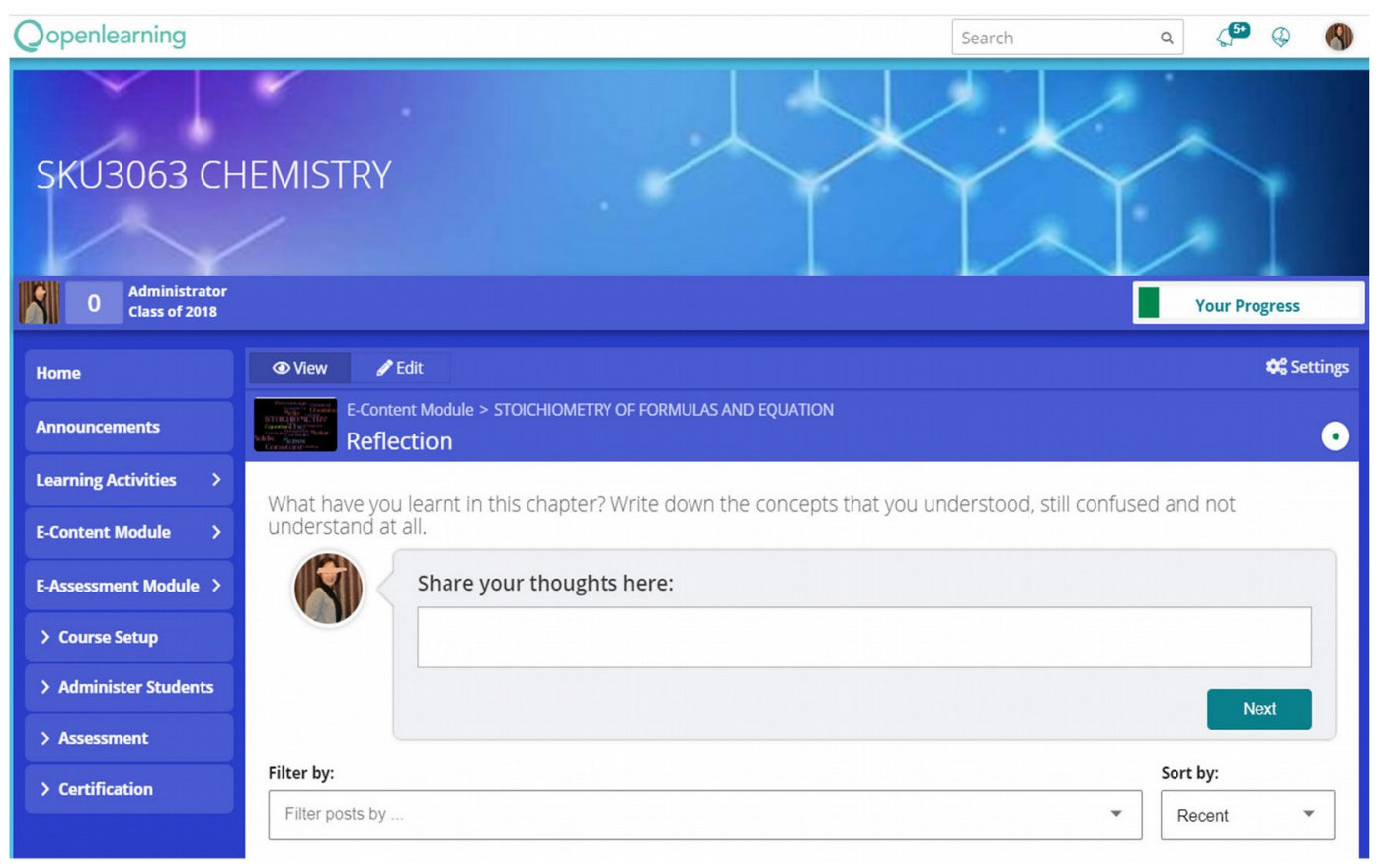

Figure 14. Reflection page

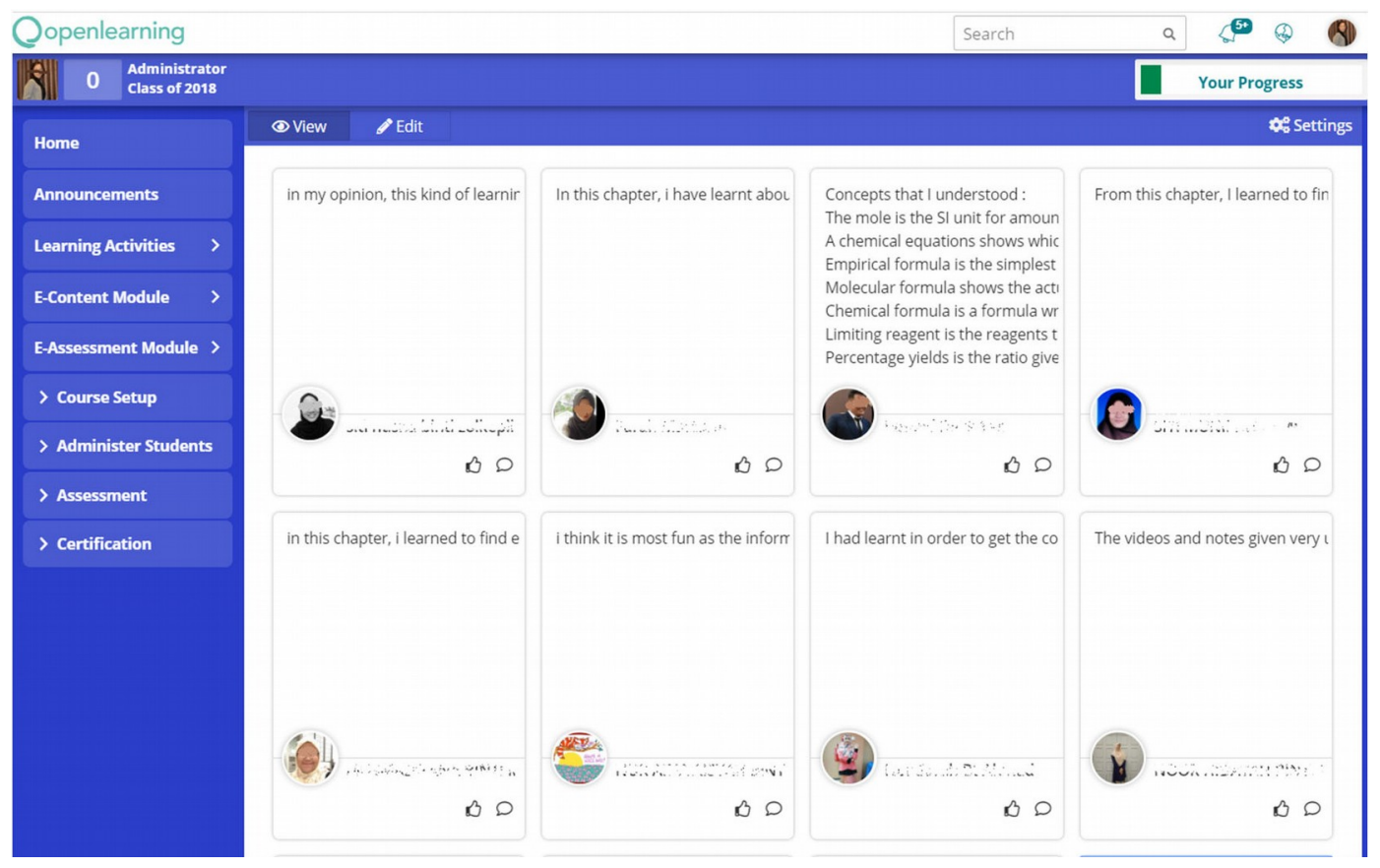

Figure 15. Students share their reflection

There are three levels of summative evaluation, level 1: perception, level 2: learning and level 3: performance (Branch, 2009). In this study, summative evaluation only involved level 1: perception. Level 1 evaluation measures students' perceptions of the course content, resources used, the physical classroom environment, or the ease of navigation in the virtual classroom environment and the teacher's facilitation style (Branch, 2009). In this study, students' perceptions in terms of content, usability, design and effectiveness of e-content module for Chemistry MOOC were studied. Perception questionnaire were developed by adapting instruments from Lee's study (2013). The findings of the students' perception on the e-content module will be discussed in the next section. 


\section{Results and Discussions}

The first objective of this study is to develop the e-content module and the descriptions on developing the module were presented in the previous section. The second objective of this study is to identify the validity of the e-content module for Chemistry MOOC. Following the advice by Lynn (1986), three experts were appointed to evaluate the content validity of the e-content module for Chemistry MOOC. They were given two months to access the e-content module in Chemistry MOOC and evaluate the relevance of the content in the module. A 4-point scale $(1=$ not relevant, $2=$ somewhat relevant, $3=$ quite relevant, $4=$ highly relevant) as recommended by Davis (1992) was applied in the content validity evaluation form in this study to avoid having ambivalent midpoint (Lynn, 1986). The experts checked each topic and all the materials in the e-content module, and they agreed that all materials were relevant to the SKU3063 Chemistry course. The findings of the content validity evaluation form showed that the I-CVI for each content is 1.00 and overall S-CVI/Ave is also 1.00. Thus, it could be concluded that e-content module for Chemistry MOOC has high content validity.

The third objective of this study is to identify the reliability of the e-content module for Chemistry MOOC. According to Russell (1974), reliability of the module is closely related to the ability of learners to fulfil all the activities presented in the module. To do this, module reliability questionnaire was distributed to the students during pilot study to investigate whether they can follow all the materials presented to them in the e-content module. Cronbach's alpha was employed to test the internal consistency of the items in each topic. All topics presented high-reliability value with Cronbach's alpha values ranging from 0.93 to 0.95 as indicated in Table 6 . The findings showed the overall reliability index of e-content module for Chemistry MOOC is 0.94. Based on Noah and Ahmad (2005), the reliability of a module can be analysed using the Cronbach's alpha method to obtain the value of reliability coefficient. If the value of Cronbach's alpha is more than 0.60 , the instrument is acceptable. If the value of Cronbach's alpha is more than 0.90 , then the instrument has very high reliability (Hair, Black, Babin \& Anderson, 2009). Hence, this study found a high reliability coefficient for the e-content module for Chemistry MOOC.

The last objective of this study is to identify students' perceptions in terms of content, usability, design and effectiveness of e-content module for Chemistry MOOC. Respondents showed their agreement on the items in the questionnaire based on 4-point Likert scale. The findings of the perception questionnaire are presented in Table 7.

\begin{tabular}{|c|l|c|}
\hline No. & \multicolumn{1}{|c|}{ Topic } & Cronbach's alpha \\
\hline 1 & Stoichiometry of Formulas and Equations & 0.94 \\
\hline 2 & Quantum Theory and Periodic Table & 0.95 \\
\hline 3 & Chemical Bonding & 0.93 \\
\hline 4 & Nuclear Chemistry & 0.94 \\
\hline & Overall & 0.94 \\
\hline
\end{tabular}

Table 6. Cronbach's alpha for each topic in the e-content module (Hamid, 2020)

\begin{tabular}{|c|l|c|c|}
\hline No. & \multicolumn{1}{|c|}{ Construct } & Mean (M) & Standard Deviation (SD) \\
\hline 1 & Content & 3.66 & 0.55 \\
\hline 2 & Usability & 3.43 & 0.56 \\
\hline 3 & Design & 3.41 & 0.59 \\
\hline 4 & Effectiveness & 3.47 & 0.56 \\
\hline
\end{tabular}

Table 7. Mean and standard deviation of constructs in perception questionnaire (Hamid, 2020)

Results showed the mean value for the content construct is the highest $(\mathrm{M}=3.66, \mathrm{SD}=0.55)$ among the constructs in the perception questionnaire. Content refers to materials presented in the e-content module, for instance PowerPoint slides and videos for Nuclear Chemistry, Quantum Theory and Periodic Table, 
Chemical Bonding, and Stoichiometry of Formulas and Equations topics. Related content provided and useful resources recommended by the educators could help learners to meet the learning outcomes (Nganji, 2018). In this study, students understood well the language used in the e-content module, both in PowerPoint slides and videos. They agreed all the learning materials are well structured, interconnected with each topic and suitable with their level of understanding. All these characteristics of e-content module seem to meet the criteria of course quality suggested by Yang, Shao, Liu and Liu (2017). These results also are paralleled with previous studies (Liu, Kang \& McKelroy, 2015; Watson, Loizzo, Watson, Mueller, Lim \& Ertmer, 2016), showing that learners have positive perception of the lecture/videos and reading/resources as impactful instructional materials within the MOOC. MOOC serves as personalised e-learning platform where learners are highly engaged with the learning content. The learners will achieve the learning outcomes and improve their performance in the long run by engaging with the learning content (Nganji, 2018).

The second construct in the perception questionnaire is usability with mean value 3.43 and standard deviation 0.56 . Usability refers to the interface of the software which could ease the users when they use the software (Alon \& Herath, 2014; Khamis, 2009; Ujang, 2016). It involves the ease of use of the learning environment, such as the navigation, how easy it is to find specific content and generally how easy it is to use the environment (Nganji, 2018). Hence, instructor needs to ensure that learning materials are available and easily accessed so that learners could manage their learning in their own time. Zalli, Nordin and Hashim (2019) found that planning, time management and self-evaluation are significant factors that influence MOOC users' satisfaction. A good navigation of MOOC could satisfy the users. Technical problems such as unable to access videos, submit scores, navigating through discussion forum made learners felt disappointed (Watson et al., 2016). To help learners remain engaged in the MOOCs, instructors should ensure the system quality by making sure that all the learning materials can be quickly loaded, the links are easily navigated and the platform functions well all the time (Yang et al., 2017).

Design is the construct with the lowest mean value, $3.41(\mathrm{SD}=0.59)$. Design involves the items about the organization, colour, graphic, interactivity, video and other elements involved in the interface of e-content module in Chemistry MOOC. Majority of the students agreed the colours used in the module are interesting, the interface design and graphics presented in the module caught their attention. Design of the MOOC is part of system quality that contributes to persistent intention of learners toward participation in the MOOCs (Yang et al., 2017). Learners perceive better learning performance when the course design such as the interface, content design and the flow of content is congruent with their learning preferences (Handoko et al., 2019). Good interface designs promote learners' levels of engagement and allow effective pedagogical principles to benefit learners (Liu et al., 2015).

The construct of effectiveness obtains the second highest mean score $(\mathrm{M}=3.47, \mathrm{SD}=0.56)$. Effectiveness in the present study refers to the impact of using e-content module on students' chemistry concept mastery. Most of the students agreed they could understand the concepts of Stoichiometry of Formulas and Equations, Quantum Theory and Periodic Table, Chemical Bonding, and Nuclear Chemistry after learning with e-content module in Chemistry MOOC. The learning material of these topics were presented to the students in the form of PowerPoint slides and videos. Studies showed that using videos as instructional material could improve students learning performance and achieve learning outcomes successfully (Bonafini, Chae, Park \& Jablokow, 2017; Chen \& Wu, 2015; Chi, Pickrell \& Riedy, 2014; Kissi, Nat \& Armah, 2018). Using videos in self-paced online learning such as MOOCs support self-regulated learning (Handoko et al., 2019; Lai \& Hwang, 2016; Zimmerman, 2013) and enable learners to engage in the learning environment at their own pace (Yakubova, Hughes \& Hornberger, 2015). A learner needs to have self-regulation to be actively involved in the learning process using MOOC (Zalli, Nordin \& Hashim, 2020).

\section{Conclusion}

The e-content module for Chemistry MOOC has been successfully developed using ADDIE instructional design model. CVI is 1.00 showing that the e-content module for Chemistry MOOC has high content 
validity. Next, the reliability coefficient of e-content module for Chemistry MOOC $(\alpha=0.94)$ demonstrated the internal consistency of the scale was acceptable. The Cronbach's alpha values ranged from 0.93 to 0.95 revealing satisfactory discriminating power. The mean scores for students' perceptions of the module ranged from 3.41 to 3.66 revealing high perception level in the content, usability, design and effectiveness constructs. This e-content module for Chemistry MOOC can be a guidance and a resource for lecturers and students who involved in the teaching and learning of Chemistry in blended learning or flipped classroom platform.

\section{Declaration of Conflicting Interests}

The authors declared no potential conflicts of interest with respect to the research, authorship, and/or publication of this article.

\section{Funding}

We would like to thank Sultan Idris Education University for funding this research grant via Geran Penyelidikan Khas Universiti (Pendidikan) under Grant no. 2018-0046-107-01.

\section{References}

Ahmad, A., Hashim, Y., Karimi, A. \& Sin, N.M. (2010). Dasar e-Pembelajaran Negara (DePAN) untuk Institusi Pengajian Tinggi. Jawatankuasa e-CAP Kementerian Pengajian Tinggi.

Ahmad, J. (2002). Kesahan, kebolehpercayaan dan keberkesanan Modul Program Maju Diri ke atas motivasi pencapaian di kalangan pelajar sekolah menengah negeri Selangor. Unpublished $\mathrm{PhD}$ thesis. Universiti Putra Malaysia, Serdang, Selangor.

Alon, I., \& Herath, K. (2014). Teaching international business via social media projects. Journal of Teaching in International Business, 25(1), 44-59. https:// doi.org/10.1080/08975930.2013.847814

Alqahtani, A. (2019). Usability testing of Google Cloud applications: Students' perspective. Journal of Technology and Science Education, 9(3), 326-339. https://doi.org/10.3926/jotse.585

Anderson, T., \& Garrison, D.R. (1998). Learning in a networked world: New roles and responsibilities. In Gibson, C. (Ed.), Distance learners in bigher education (97-112). Madison, WI: Atwood Publishing.

Anderson, T. (2003). Getting the mix right again: An updated and theoretical rationale for interaction. The International Review of Research in Open and Distributed Learning, 4(2), 1-14.

https://doi.org/10.19173/irrodl.v4i2.149

Baharin, Y., \& Yusop, F.D. (2011). Pembelajaran kolaboratif menggunakan blog dalam perlaksanaan pembelajaran mata pelajaran Ekonomi Asas. Jurnal Pendidikan, 1, 79-89.

Baker, P.M.A., Bujak, K.R., \& DeMillo, R. (2012). The evolving university: Disruptive change and institutional innovation. Procedia Computer Science, 14, 330-335. https://doi.org/10.1016/j.procs.2012.10.037

Baser, D., Ozden, M.Y., \& Karaarslan, H. (2017). Collaborative project-based learning: An integrative science and technological education project. Research in Science \& Technological Education, 35(2), 131-148. https://doi.org/10.1080/02635143.2016.1274723

Baturay, M.H. (2015). An overview of the world of MOOCs. Procedia-Social and Behavioral Sciences, 174, 427-433. https://doi.org/10.1016/j.sbspro.2015.01.685

Blackman, A.G., Bottle, S.E., Schmid, S., Mocerino, M., Wille, U., Brady, J.E., et al. (2016). Chemistry (3rd ed.). Milton, Qld: John Wiley \& Sons Australia.

Bonafini, F.C., Chae, C., Park, E., \& Jablokow, K.W. (2017). How much does student engagement with videos and forums in a MOOC affect their achievement? Online Learning, 21(4), 223-240.

https://doi.org/10.24059/olj.v21i4.1270 
Branch, R.M. (2009). Instructional design: The ADDIE approach. New York, NY: Springer. https://doi.org/10.1007/978-0-387-09506-6

Chen, C.M., \& Wu, C.H. (2015). Effects of different video lecture types on sustained attention, emotion, cognitive load, and learning performance. Computers \& Education, 80, 108-121.

https://doi.org/10.1016/j.compedu.2014.08.015

Chi, D.L., Pickrell, J.E., \& Riedy, C.A. (2014). Student learning outcomes associated with video vs. paper cases in a public health dentistry course. Journal of Dental Education, 78(1), 24-30.

https://doi.org/10.1002/j.0022-0337.2014.78.1.tb05653.x

Conrad, R., \& Donaldson, A. (2004). Engaging the online learner. San Francisco, CA: Jossey-Bass.

Davis, L.L. (1992). Instrument review: Getting the most from your panel of experts. Applied Nursing Research, 5, 194-197. https://doi.org/10.1016/S0897-1897(05)80008-4

Department of Higher Education (n.d.). Dasar e-Pembelajaran Negara 2.0. Putrajaya: Ministry of Higher Education.

Duke, B., Harper, G., \& Johnston, M. (2013). Connectivism as a digital age learning theory. The International HETL Review, Special Issue 2013, 4-13.

Embi, M.A., Nordin, N., Husin, S., \& Hamat, A. (2010). Rumusan amalan, trend dan cabaran perlaksanaan e-pembelajaran di IPT Malaysia. In Embi, M.A. (Ed.), Amalan keberkesanan dan cabaran perlaksanaan e-pembelajaran di IPT Malaysia (111-122). Putrajaya: Kemeterian Pendidikan Tinggi Malaysia.

First MOOC (2013). First MOOC in Malaysia Launched. Taylor's School of Engineering Blueprint, 4(3). Available at: https://university2.taylors.edu.my/download/blue-print-newsletter-2013-march-issue.pdf

Ghani, A.A. (2012). Penggunaan sistem e-pembelajaran author dalam pengajaran dan pembelajaran di UTHM. Available at: http://eprints.uthm.edu.mv/4214/

Guo, P.J., Kim, J., \& Rubin, R. (2014). How video production affects student engagement: An empirical study of MOOC videos. Proceedings of the First ACM Conference on Learning @ Scale Conference (41-50), Atlanta: GA. https://doi.org/10.1145/2556325.2566239

Hair, J., Black, W., Babin, B., \& Anderson, R. (2009). Multivariate data analysis (7th ed.). Upper Saddlr River: Prentice-Hall.

Hamid, S.N.M. (2020). Pembangunan modul e-kandungan untuk Massive Open Online Course (MOOC) kimia. Unpublished master thesis. Universiti Pendidikan Sultan Idris, Tanjong Malim, Perak.

Hamidon, Z. (2014). Tahap pengekalan, enrolment dan proses pembelajaran dalam kursus MOOC: Satu tinjauan awal. Presented in Seminar Kebangsaan Sepanjang Hayat: PSH Tonggak Ketiga Pembangunan Modal Insan, Dewan Tun Hussien Onn, PWTC, KL. Ministry of Education \& OUM.

Handoko, E., Gronseth, S.L., McNeil, S.G., Bonk, C.J., \& Robin, B.R. (2019). Goal setting and MOOC completion: A study on the role of self-regulated learning in student performance in massive open online courses. International Review of Research in Open and Distributed Learning, 20(3), 39-58.

https://doi.org/10.19173/irrodl.v20i4.4270

Hervatta, N. (2016). Designing the interaction among learners and educators in MOOCs (Order No. 10111621). ProQuest Dissertations \& Theses Global. (1799665050). Available at: https://search.proquest.com/docview/1799665050?accountid=13155

Hollands, F.M., \& Tirthali, D. (2014). MOOCs: Expectations and reality. Full report. Center for Benefit-Cost Studies of Education, Teachers College, Columbia University, NY. Available at: http://cbcse.org/wordpress/wpcontent/uploads/2014/05/MOOCs Expectations and Reality.pdf

Khamis, M.A. (2009). Teaching and learning technology. Cairo: Dar Al Sahab Publishing \& Distribution Library. 
Kissi, P.S., Nat, M., \& Armah, R.B. (2018). The effects of learning-family conflict, perceived control over time and task-fit technology factors on urban-rural high school tudents' acceptance of video-based instruction in flipped learning approach. Educational Technology Research and Development, 66, 1547-1569. https://doi.org/10.1007/s11423-018-9623-9

Krejcie, R.V., \& Morgan, D.W. (1970). Determining sample size for research activities. Educational and Psychological Measurement, 30, 607-610. https://doi.org/10.1177/001316447003000308

Lagerstrom, L., Johanes, P., \& Ponsukcharoen, M.U. (2015). The myth of six-minutes rule: Student engagement with online videos. Proceedings of the American Society for Engineering Evolution, June, 14-17. Seattle; WA. https://doi.org/10.18260/p.24895

Lai, C.L., \& Hwang, G.J. (2016). A self-regulated flipped classroom approach to improving students' learning performance in a mathematics course. Computers \& Education, 100, 126-140. https://doi.org/10.1016/j.compedu.2016.05.006

Lee, T.T., \& Osman, K. (2012). Interactive multimedia module with pedagogical agents: Formative evaluation. International Education Studies, 5(6), 50-64. https://doi.org/10.5539/ies.v5n6p50

Lee, T.T. (2013). Pembinaan dan keberkesanan modul multimedia interaktif dengan agen pedagogi dalam pembelajaran elektrokimia. Unpublished $\mathrm{PhD}$ thesis. Universiti Kebangsaan Malaysia, Bangi, Selangor.

Lee, T.T., Sharif, A.M., \& Rahim, N.A. (2018). Designing e-content for teaching basic chemistry concepts in higher education: Needs analysis. Journal of Turkish Science Education, 15(4), 65-78.

Littlejohn, A. (2013). Understanding massive open online courses. CEMCA EdTech Notes. Available at: http://cemca.org.in/ckfinder/userfiles/files/EdTech\%20Notes\%202 Littlejohn final 1June2013.pdf

Liu, M., Kang, J., \& McKelroy, E. (2015). Examining learners' perspective of taking a MOOC: Reasons, excitement, and perception of usefulness. Educational Media International, 52(2), 129-146. https://doi.org/10.1080/09523987.2015.1053289

Liyanagunawardena, T.R., Adams, A.A., \& Williams, S.A. (2013). MOOCs: A systematic study of the published literature 2008 2012. The International Review of Research in Open and Distance Learning, 14(3), 202-227. https://doi.org/10.19173/irrodl.v14i3.1455

Low, G.S. (2014). Pembangunan perisian matematik bulatan I dan kesan penggunaannya terhadap murid bermasalah pendengaran. Unpublished master thesis. Universiti Pendidikan Sultan Idris, Tanjong Malim, Perak.

Lynn, M.R. (1986). Determination and quantification of content validity. Nursing Research, 35, 382-385. https://doi.org/10.1097/00006199-198611000-00017

Mackness, J., Mak, S., \& Williams, R. (2010). The ideals and reality of participating in a MOOC. In Dirckinck-Holmfeld, L., Hodgson, V., Jones, C., de Laat, M., McConnell, D., \& Ryberg, T. (Eds.), Proceedings of the 7th International Conference on Networked Learning 2010 (266-274). UK: University of Lancaster.

Mat-jizat, J.E., Samsudin, N. \& Yahaya, R. (2014). Higher Education Institution (HEIs) students take on MOOC: Case of Malaysia. Paper presented in 11th International Conference on Cognition and Exploratory Learning in Digital Age (CELDA 2014) (25-27). Porto, Portugal.

Ministry of Education Malaysia (2012). Laporan awal Pelan Pembangunan Pendidikan Malaysia 2013 -2025. Putrajaya: Kementerian Pendidikan Malaysia.

Ministry of Education Malaysia (2014). E-Learning guidelines for Malaysian HEIs. Putrajaya: Department of Higher Education, Ministry of Education Malaysia.

Ministry of Education Malaysia (2015). Executive Summary Malaysia Education Blueprint 2015-2025 (Higher Education). Putrajaya: Ministry of Education Malaysia. 
Nganji, J.T. (2018). Towards learner-constructed e-learning environments for effective personal learning experiences. Behaviour \& Information Technology, 37(7), 647-657.

https://doi.org/10.1080/0144929X.2018.1470673

Nichols, M., \& Anderson, T. (2005). Strategik perlaksanaan e-pembelajaran. Teknologi Pendidikan \& Society, $4,1-8$.

Noah, S.M., \& Ahmad, J. (2005). Pembinaan modul: Bagaimana membina modul latihan dan modul akademik. Serdang: Universiti Putra Malaysia.

OpenLearning Global (2014). Malaysia's MOOCs attract over 6000 students! Available at: https://learninghub.openlearning.com/2014/04/17/malaysias-moocs-attract-over-6000-students/

Polit, D.F., \& Beck, C.T. (2006). The content validity index: Are you sure you know what's being reported? Critique and recommendations. Research in Nursing \& Health, 29, 489-497. https://doi.org/10.1002/nur.20147

Reinbold, S. (2013). Using the ADDIE model in designing library instructions. Medical References Services Quarterly, 3, 244-256. https://doi.org/10.1080/02763869.2013.806859

Russell, J.D. (1974). Modular instruction: A guide to design, selection, utilization and evaluation of modular materials. Minneapolis, MN: Burgess Publishing Company.

Saadatdoost, R., Sim, A.T.H., Jafarkarii, H., \& Hee, J.M. (2015). Exploring MOOC from education and information systems perspectives: A short literature review. Educational Review, 67(4), 505-518. https://doi.org/10.1080/00131911.2015.1058748

Siemens, G. (2005). Connectivism: A learning theory for the digital age. International Journal of Instructional Technology \& Distance Learning, 2(1), 3-10. Available at: https://iotamac.typepad.com/jotamacs weblog/files/Connectivism.pdf

Silberberg, M.S. (2013). Chemistry: The molecular nature of matter and change (Global ed.). New York: McGraw-Hill.

Siraj, S., Alias, N., DeWitt, D., \& Hussin, Z. (2013). Design and developmental research: Emergent trends in educational research. Kuala Lumpur: Pearson Malaysia Sdn. Bhd.

Ujang, A. (2016). Pembangunan modul pembelajaran webquest pendidikan kesihatan untuk guru pelatih murid bermasalah pembelajaran. Unpublished $\mathrm{PhD}$ thesis. Universiti Malaya, Kuala Lumpur.

Watson, S.L., Loizzo, J., Watson, W.R., Mueller, C., Lim, J., \& Ertmer, P.A. (2016). Instructional design, facilitation, and perceived learning outcomes: An exploratory case study of a human trafficking MOOC for attitudinal change. Educational Technology Research and Development, 64, 1273-1300. https://doi.org/10.1007/s11423-016-9457-2

Yahaya, A., Hashim, S., Ramli, J., Boon, Y., \& Hamdan, A.R. (2007). Menguasai penyelidikan dalam pendidikan: Teori, analisis dan interpretasi data. Kuala Lumpur: PTS Professional Publishing Sdn. Bhd.

Yakubova, G., Hughes, E.M., \& Hornberger, E. (2015). Video-based intervention in teaching fraction problem-solving to students with autism spectrum disorder. Journal of Autism and Developmental Disorders, 45(9), 2865-2875. https://doi.org/10.1007/s10803-015-2449-y

Yang, M., Shao, Z., Liu, Q., \& Liu, C. (2017). Understanding the quality factors that influence the continuance intention of students toward participation in MOOCs. Educational Technology Research and Development, 65, 1195-1214. https://doi.org/10.1007/s11423-017-9513-6 
Zalli, M.M.M., Nordin, H., \& Hashim, R.A. (2019). The role of self-regulated learning Strategies on learners' satisfaction in Massive Open Online Course (MOOC): Evidence from Malaysia MOOC. International Journal of Innovative Technology and Exploring Engineering (IJITEE), 8(10), 2286-2290.

https://doi.org/10.35940/ijitee.J1138.0881019

Zalli, M.M.M., Nordin, H., \& Hashim, R.A. (2020). Online self-segulated learning strategies in MOOCs: A measurement model. International Journal of Engineering and Technology, 15(8), 255-263.

https://doi.org/10.3991/ijet.v15i08.12401

Zhu, M., \& Bonk, C.J. (2019). Designing MOOCs to facilitate participant self-monitoring for self-directed learning. Online Learning, 23(4), 106-134. https://doi.org/10.24059/olj.v23i4.2037

Zimmerman, B.J. (2013). From cognitive modeling to self-regulation: A social cognitive career path. Educational Psychologist, 48(3), 135-147. https://doi.org/10.1080/00461520.2013.794676

\section{Appendix}

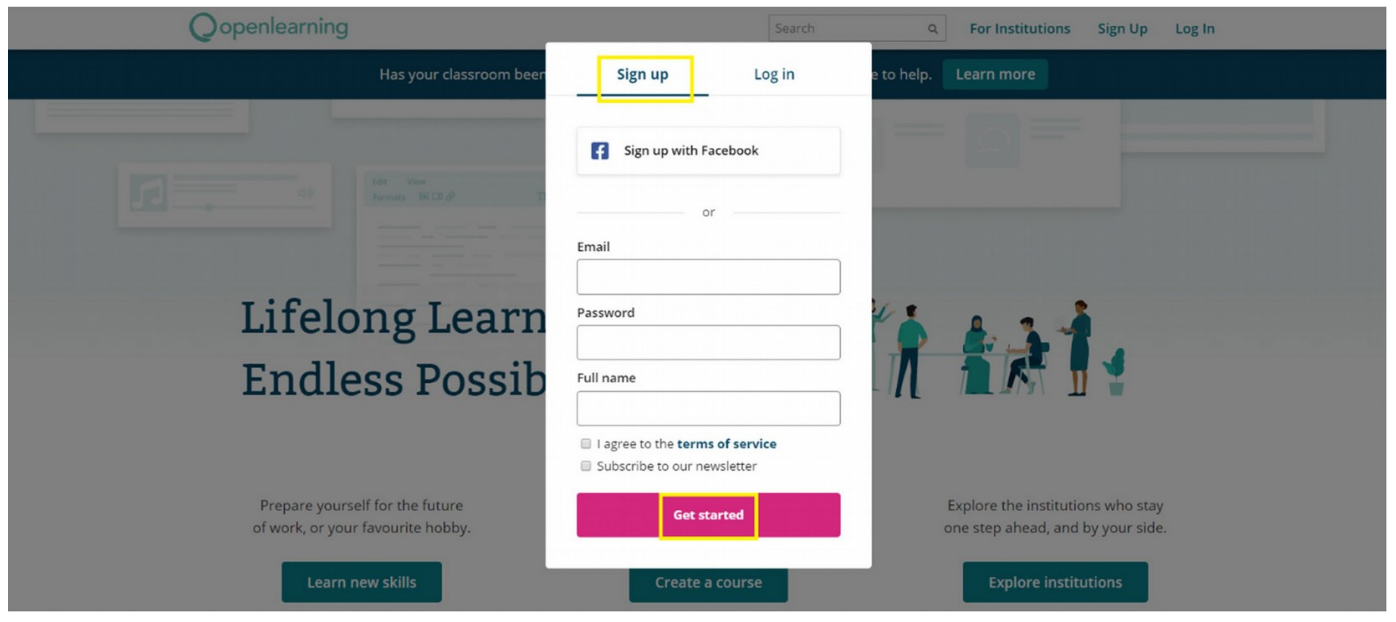

Appendix 1.1 Register an account in OpenLearning homepage

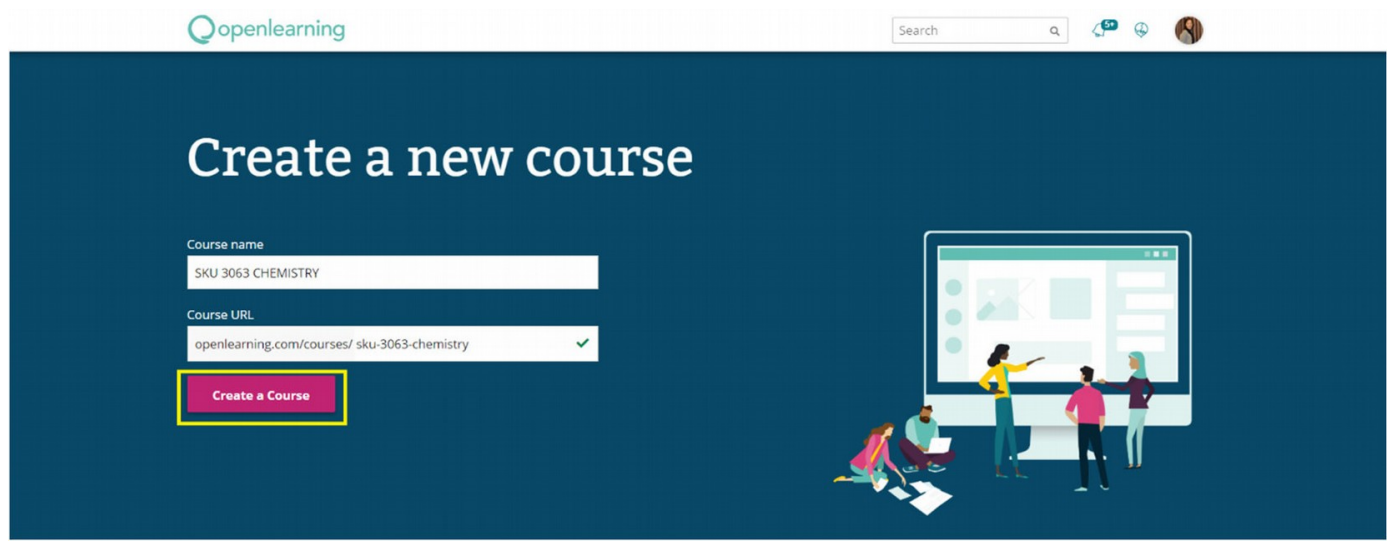

Appendix 1.2 Fill in the information to create a course 


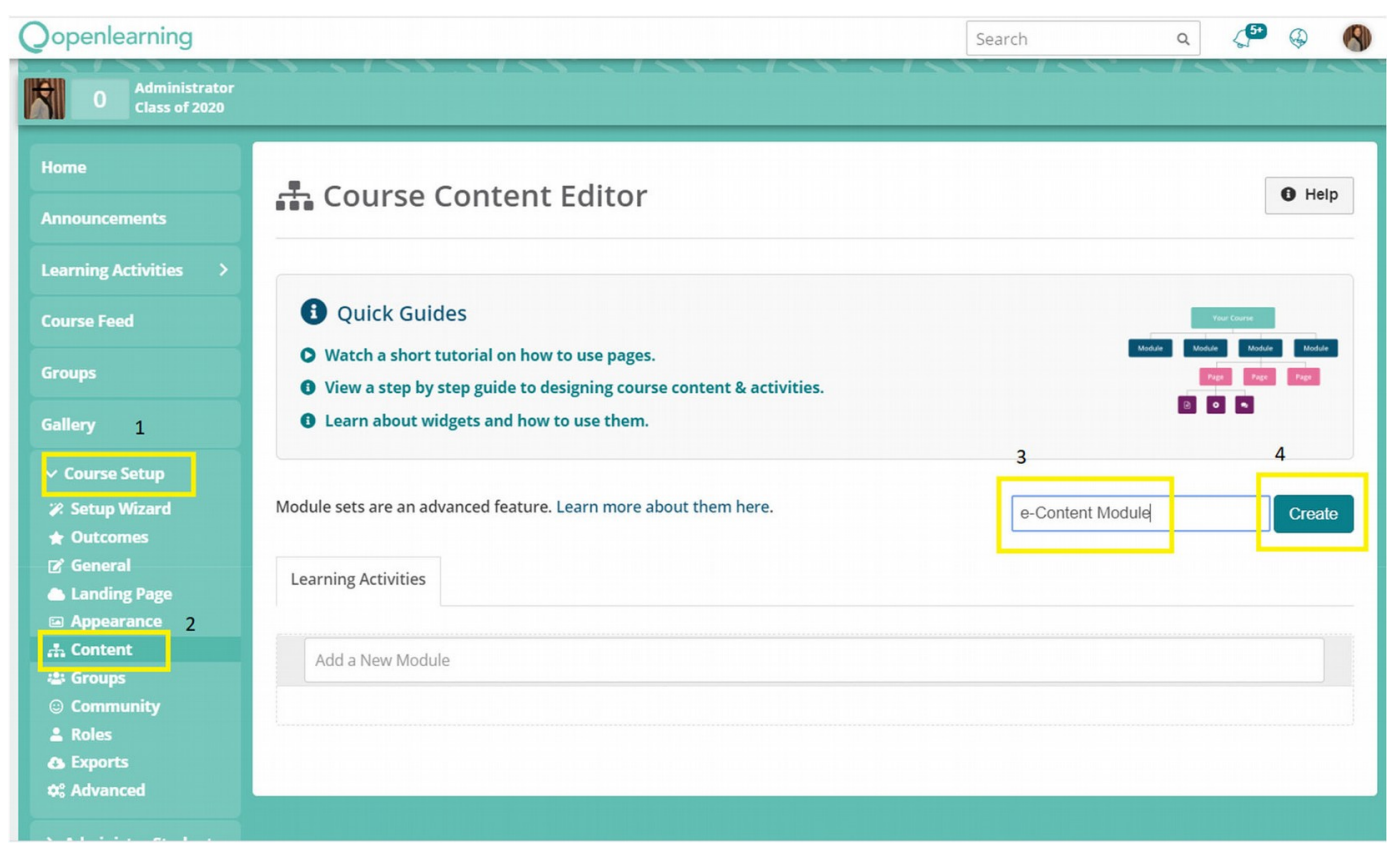

Appendix 1.3 Creating e-content module

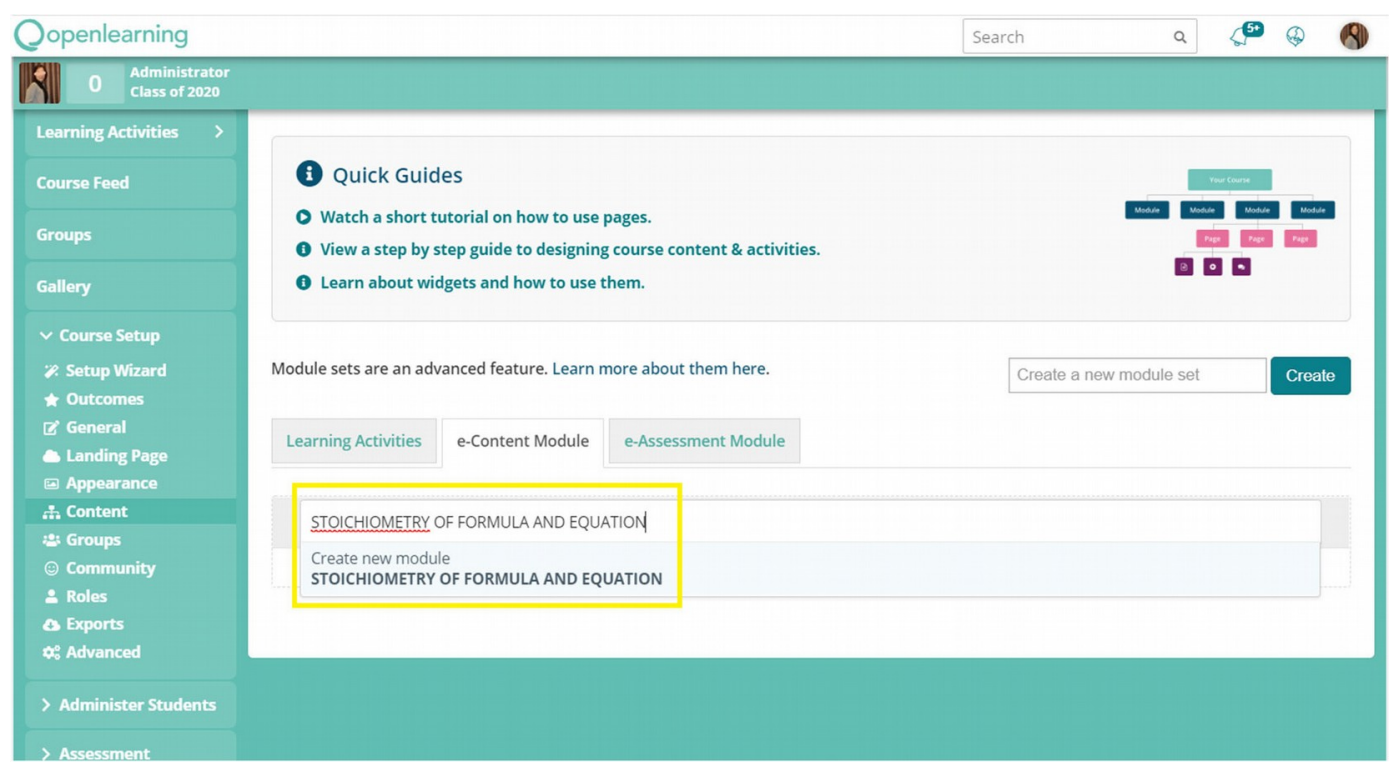

Appendix 1.4 Create topic in the module 


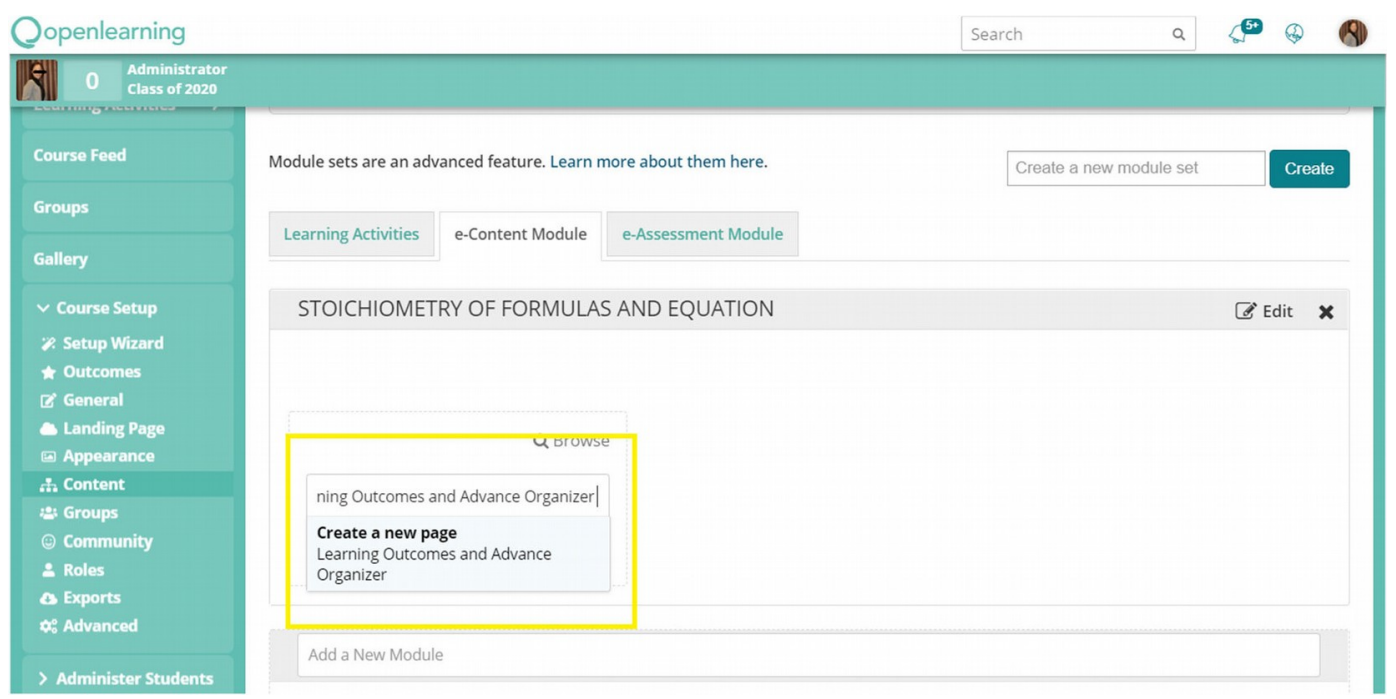

Appendix 1.5 Creating Learning Outcomes and Advance Organizer page

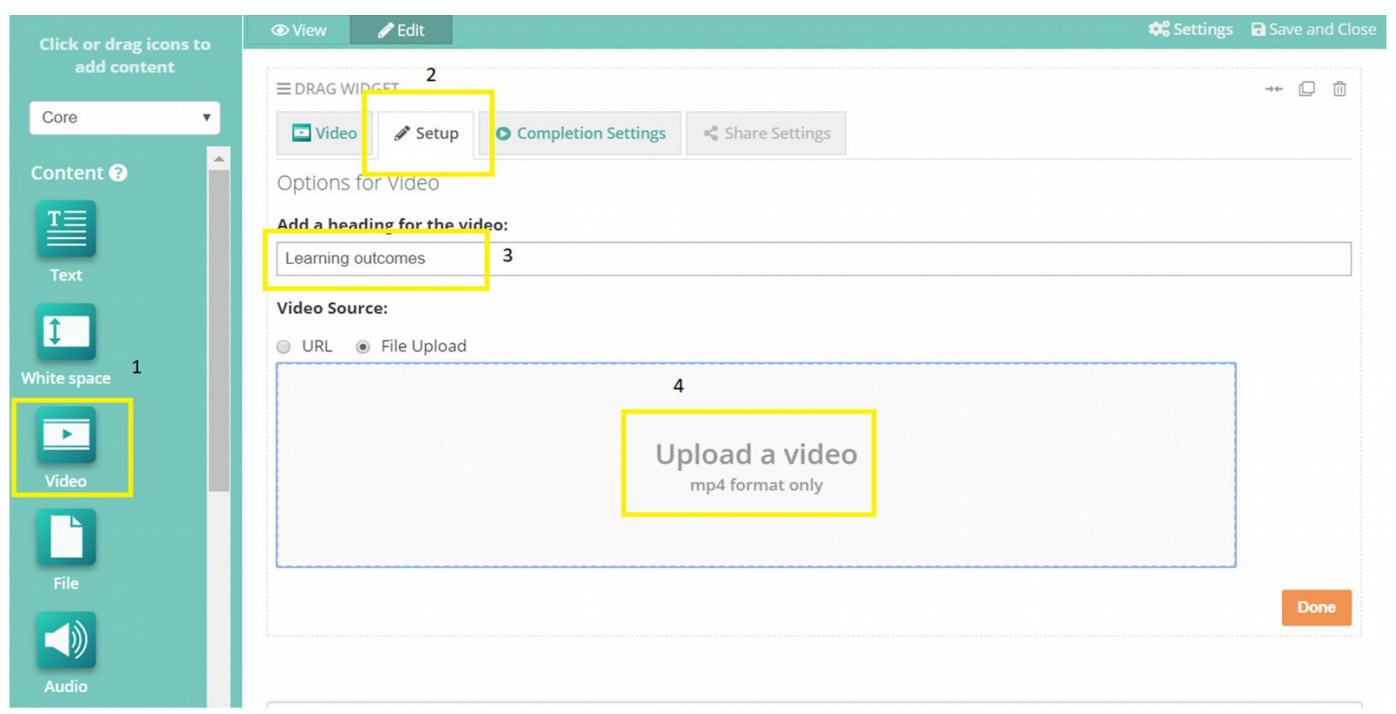

Appendix 1.6 Upload video using 'Video' widget

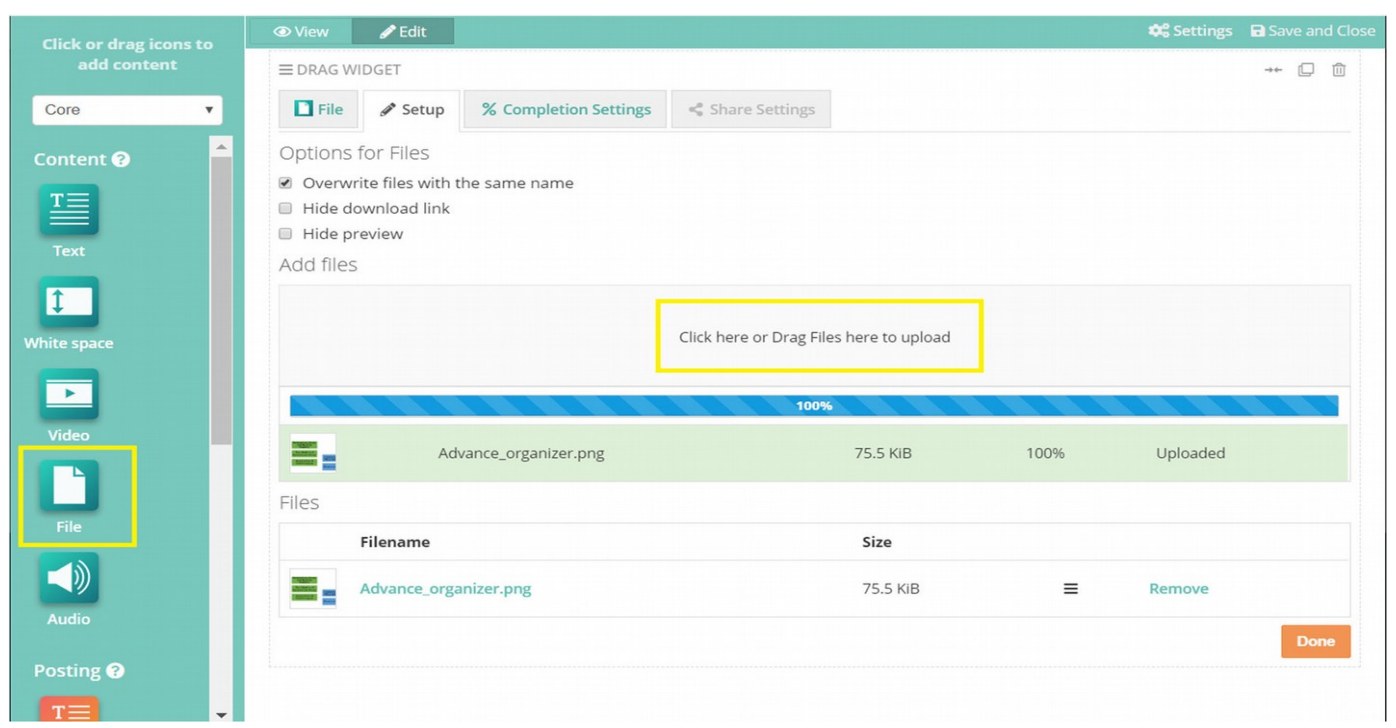

Appendix 1.7 Insert picture by uploading the file from computer 


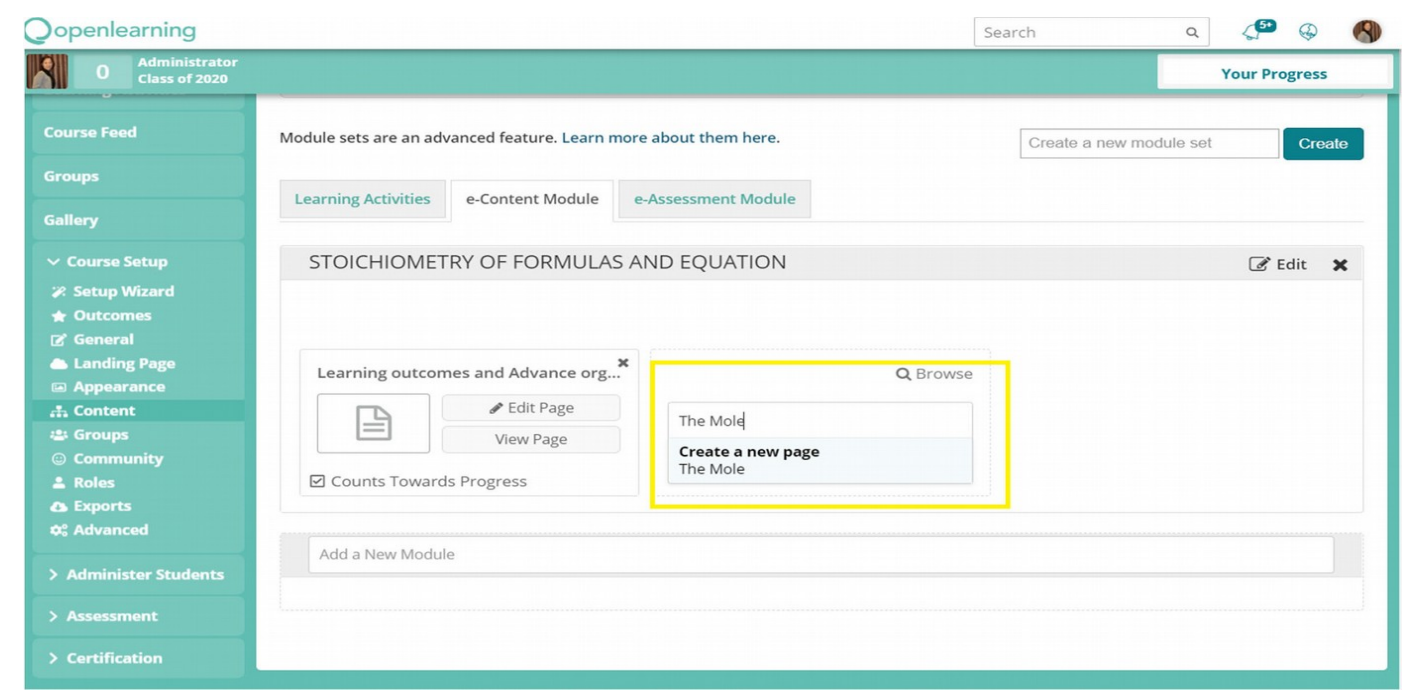

Appendix 1.8 Insert new page for subtopic

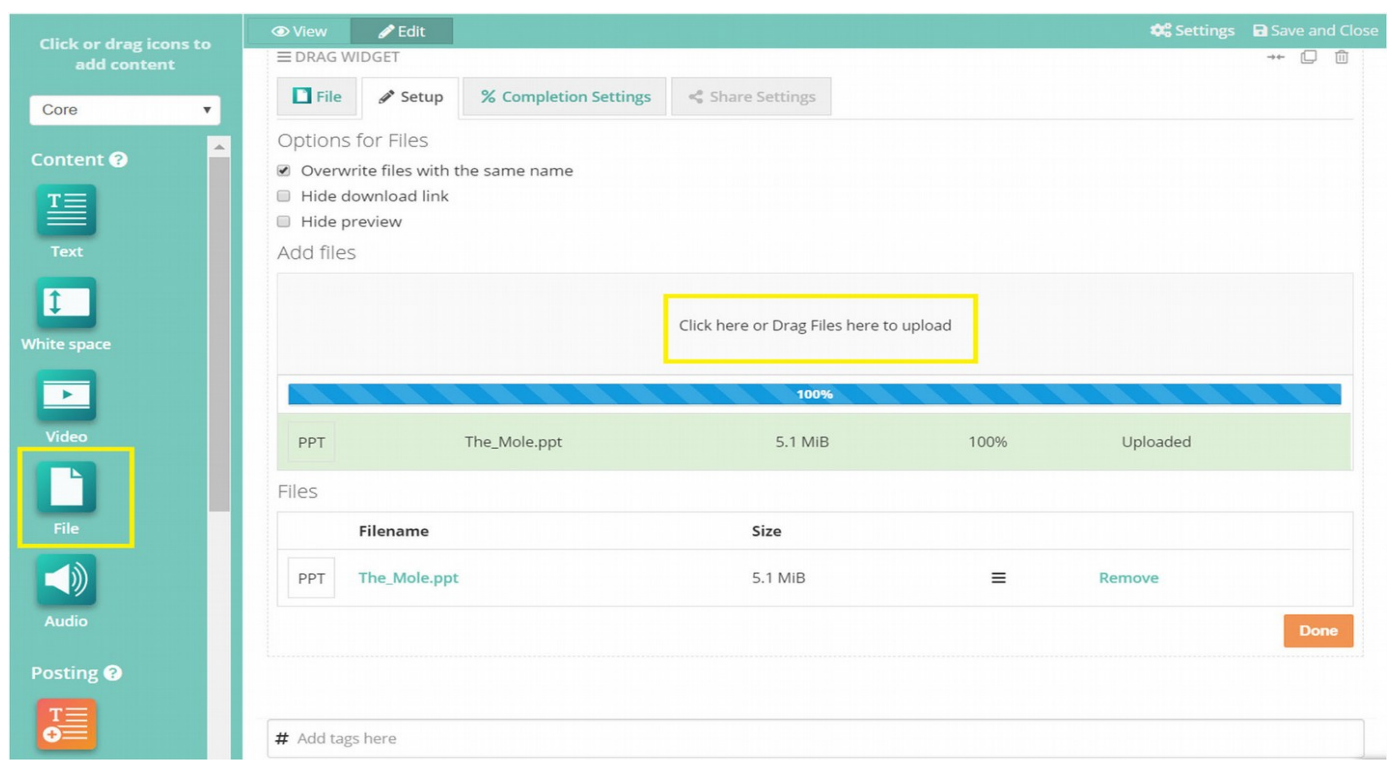

Appendix 1.9 Upload PowerPoint slides using 'File' widget

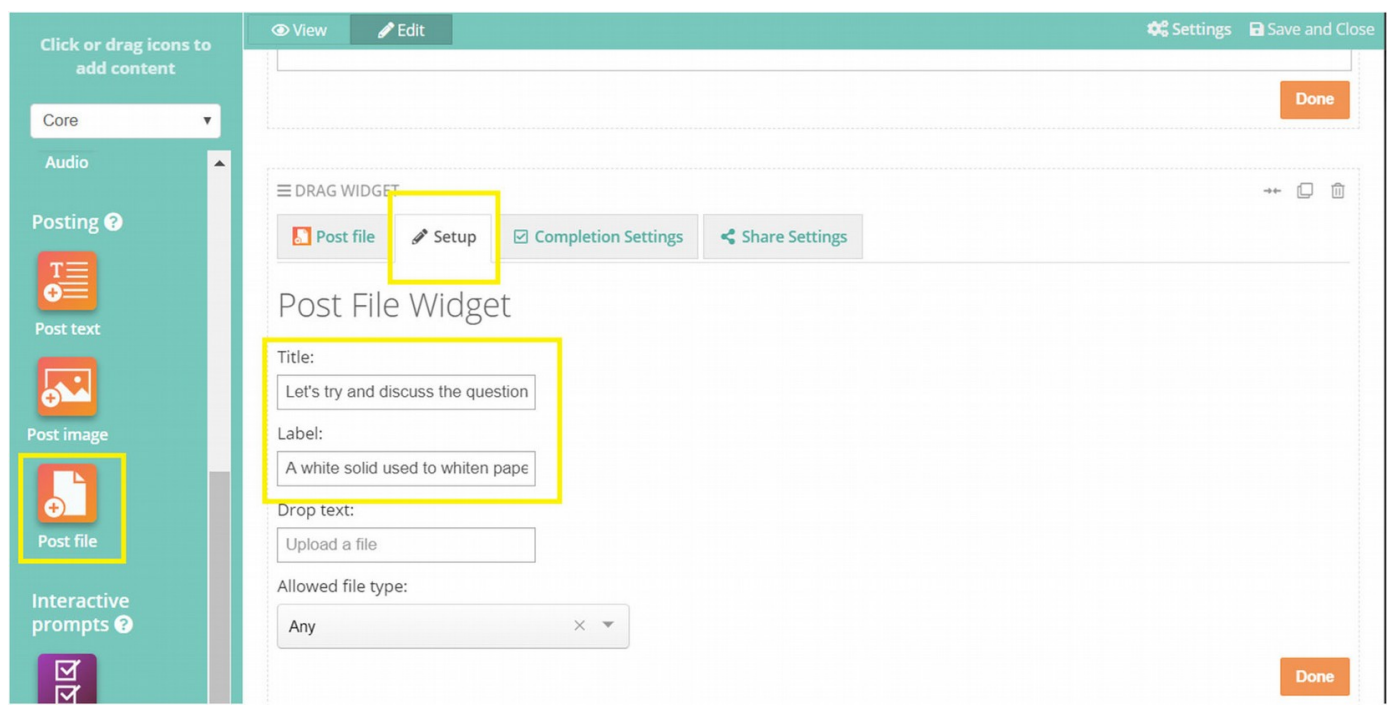

Appendix 1.10 Develop discussion page using 'Post file' widget 


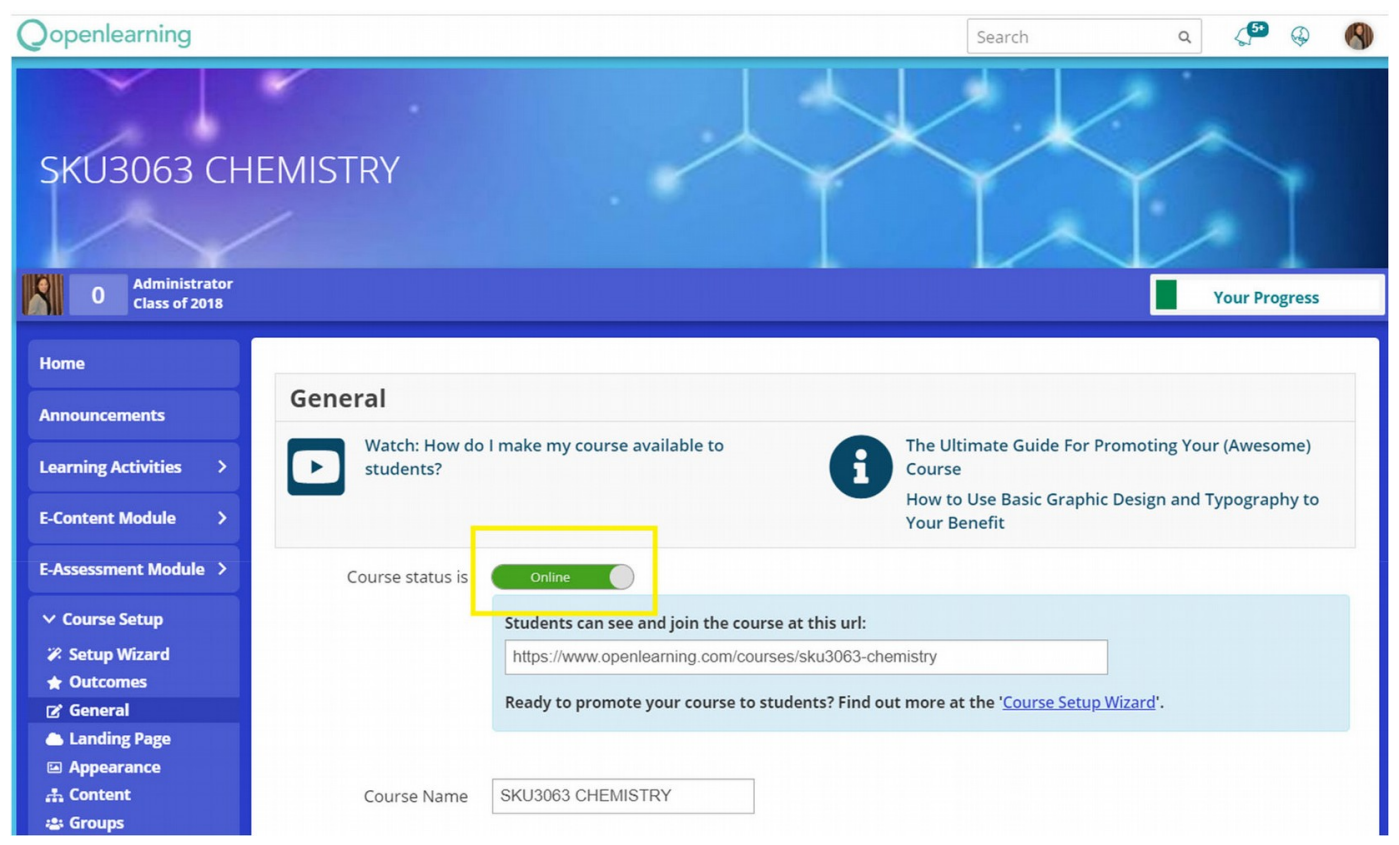

Appendix 1.11 Change the status to online

Published by OmniaScience (www.omniascience.com)

Journal of Technology and Science Education, 2021 (www.jotse.org)

\section{(). $(1) \Theta$}

Article's contents are provided on an Attribution-Non Commercial 4.0 Creative commons International License.

Readers are allowed to copy, distribute and communicate article's contents, provided the author's and JOTSE journal's names are included. It must not be used for commercial purposes. To see the complete licence contents, please visit https://creativecommons.org/licenses/by-nc/4.0/. 